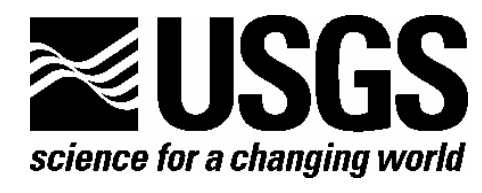

\title{
Comments on Potential Geologic and Seismic Hazards Affecting Proposed Liquefied Natural Gas Site in Santa Monica Bay, California
}

By Stephanie L. Ross ${ }^{1}$, Homa J. Lee ${ }^{1}$, Tom E. Parsons ${ }^{1}$, Larry A. Beyer ${ }^{1}$, David M. Boore ${ }^{1}$, James E. Conrad ${ }^{1}$, Brian D. Edwards ${ }^{1}$, Michael A. Fisher ${ }^{1}$, Arthur D. Frankel ${ }^{1}$, Eric L. Geist ${ }^{1}$, Kenneth W. Hudnut ${ }^{1}$, Susan E. Hough ${ }^{1}$, Robert E. Kayen ${ }^{1}$, Thomas D. Lorenson ${ }^{1}$, Nicolas Luco', Patricia A. McCrory ${ }^{1}$, Mary L. McGann ${ }^{1}$, Manuel Nathenson ${ }^{1}$, Michael Nolan ${ }^{1}$, Mark D. Petersen ${ }^{1}$, Daniel J. Ponti ${ }^{1}$, Charles L. Powell ${ }^{1}$, Holly F. Ryan ${ }^{1}$, John C. Tinsley ${ }^{1}$, Chris J. Wills ${ }^{2}$, Florence L. Wong ${ }^{1}$, and Jingping $\mathrm{Xu}^{1}$

Open-File Report 2008-1344

${ }^{1}$ U.S. Geological Survey
${ }^{2}$ California Geological Survey

U.S. Department of the Interior

U.S. Geological Survey 


\section{U.S. Department of the Interior \\ DIRK KEMPTHORNE, Secretary}

\section{U.S. Geological Survey \\ Mark D. Myers, Director}

U.S. Geological Survey, Reston, Virginia 2008

For product and ordering information:

World Wide Web: http://www.usgs.gov/pubprod

Telephone: 1-888-ASK-USGS

For more information on the USGS—-the Federal source for science about the Earth, its natural and living resources, natural hazards, and the environment:

World Wide Web: http://www.usgs.gov

Telephone: 1-888-ASK-USGS

Suggested citation:

Ross, Stephanie L., Lee, Homa J., Parsons, Tom E., Beyer, Larry A., Boore, David M., Conrad, James E., Edwards, Brian D., Fisher, Michael A., Frankel, Arthur D., Geist, Eric L., Hudnut, Kenneth W., Hough, Susan E., Kayen, Robert E., Lorenson, Thomas D., Luco, Nicolas, McCrory, Patricia A., McGann, Mary L., Nathenson, Manuel, Nolan, Michael, Petersen, Mark D., Ponti, Daniel J., Powell, Charles L., Ryan, Holly F., Tinsley, John C., Wills, Chris J., Wong, Florence L., and, Jingping Xu, 2008, Comments on potential geologic and seismic hazards affecting proposed liquefied natural gas site in Santa Monica Bay, California: U.S. Geological Survey Open-File Report 2008-1344, 60 p. [http://pubs.usgs.gov/of/2008/1344/].

Any use of trade, product, or firm names is for descriptive purposes only and does not imply endorsement by the U.S. Government.

Although this report is in the public domain, permission must be secured from the individual copyright owners to reproduce any copyrighted material contained within this report. 


\section{Contents}

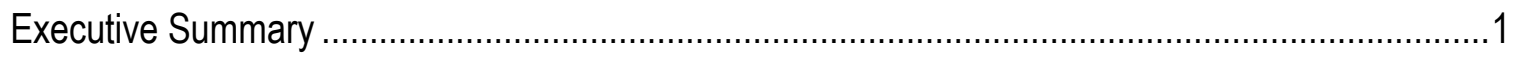

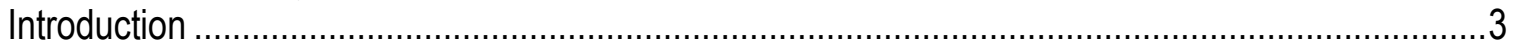

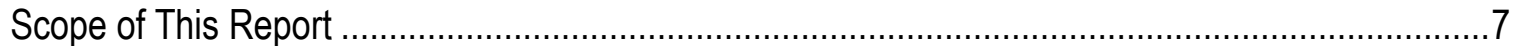

Overview of Geologic Hazards in the Proposed Area ..........................................................

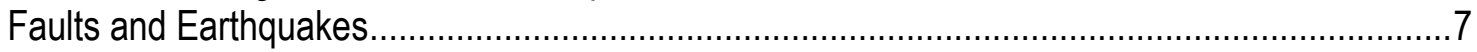

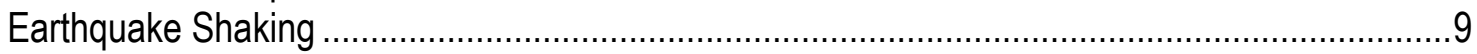

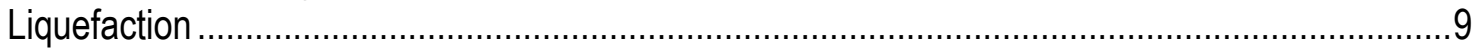

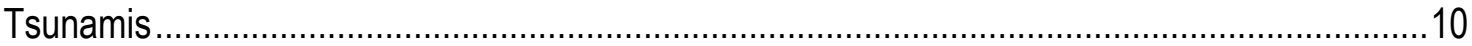

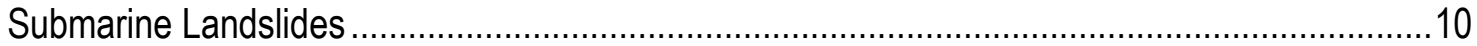

Turbidity Currents and Debris Flows ............................................................................. 10

Overview of Our Comments on Fugro West, Inc., Document "Exhibit B Topic Report 6 -

Geological Resources".....

Recommended Improvements for Future Analyses Based on Information that Existed When the Geological Resources Document was Prepared...............................................................12

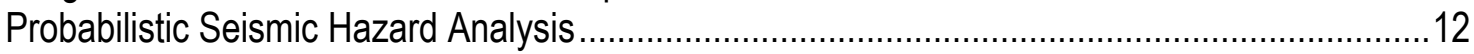

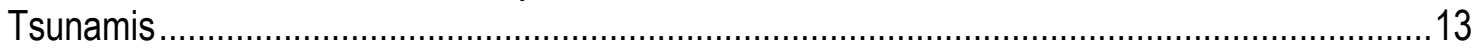

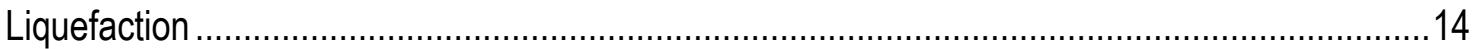

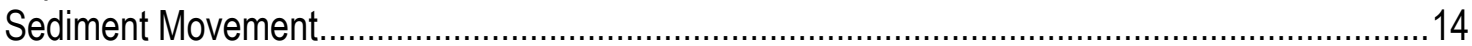

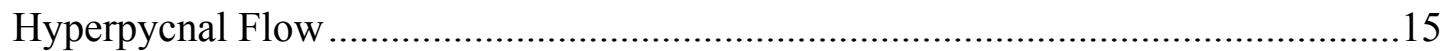

Debris Flows and Turbidity Currents....................................................................15

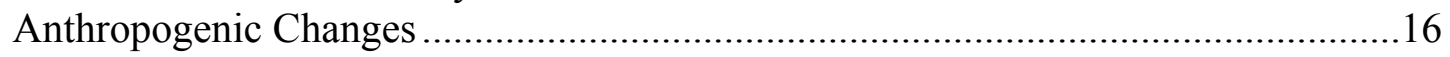

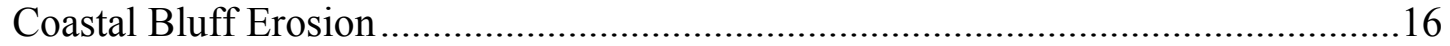

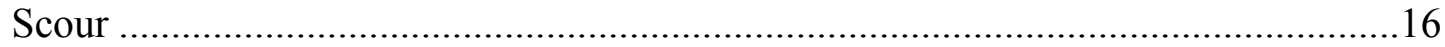

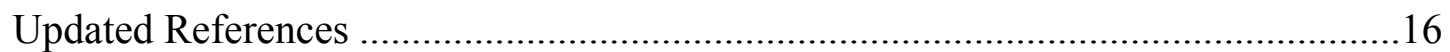

Deformation Due to Pipeline Settling, Sand Waves, and Petroleum Fields .............................17

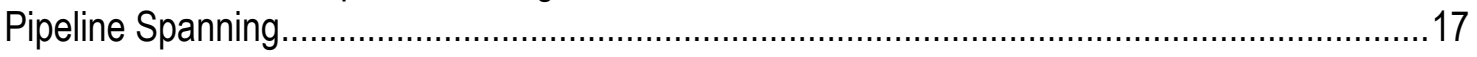

Storm Waves .............................................................................................................

Recommended Improvements for Future Analyses Based on New Consensus Reports-

Probabilistic Seismic Hazard Analysis ............................................................................17

Additional Suggestions for Further Studies ..........................................................................22

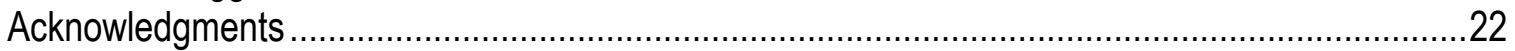

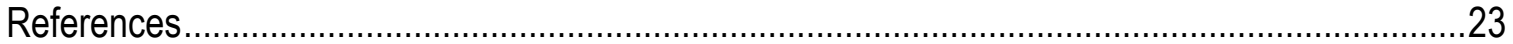

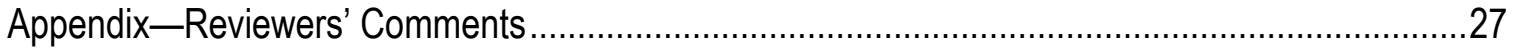

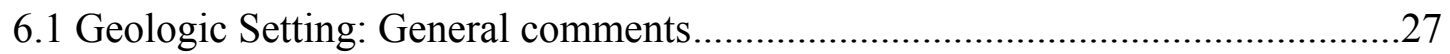

6.1.1 Tectonic Setting_Specific comments: Reviewer 1 ..............................................29

6.1.1 Tectonic Setting: Reviewer 2 …......................................................................30

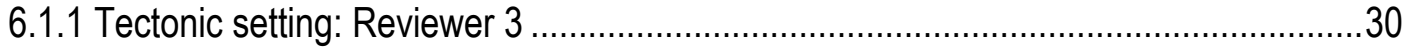

6.1.1 Tectonic Setting: Reviewer 4 ……................................................................30

6.1.2 Regional physiography and geomorphology: Reviewer 1 ......................................31

6.1.2 Regional Physiography and Geomorphology: Reviewer 2 ……..............................31

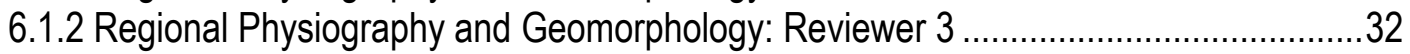

6.1.3 Regional Geology and Stratigraphy: Reviewer 1 ..................................................32

6.1.3 Regional Geology and Stratigraphy: Reviewer 2 …............................................32 
6.1.3.1 Stratigraphy of proposed site and 6.4.2.4 Stratigraphy of AES site: Reviewer 1 ..32

6.1.3.1 Stratigraphy: Reviewer 2

Section 6.1.3.2 HDD Shore Crossing Soils and Stratigraphy (and relevant parts of appendix N): Reviewer 1 .....................................................................................33

6.1.3.2 HDD Shore Crossing Soils and Stratigraphy: Reviewer 2 ….............................33

6.1.4.1 Active faults: Reviewer 1 ...........................................................................33

6.1.4.1 Active Faults: Reviewer 2 …..................................................................34

6.1.4.2 and 6.1.4.3: Historical Seismicity and Seismicity Catalog.................................34

6.1.4.4-6.1.4.7 Design Criteria for LNG Facilities, NFPA Maximum Credible Earthquake (MCE), NFPA Operating Basis Earthquake (OBE) and NFPA Safe Shutdown Earthquake

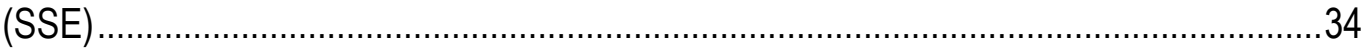

6.1.5. Sediment Transport and Depositional Environments ............................................35

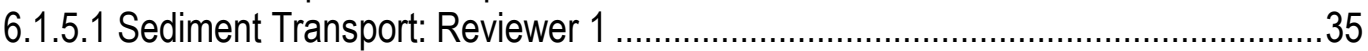

6.1.5.1 Sediment Transport: Reviewer 2 ……......................................................36

6.1.5.2 Depositional Environments: Reviewer 1 …………………............................37

6.1.5.2 Depositional Environment: Reviewer 2 ……………………………............37

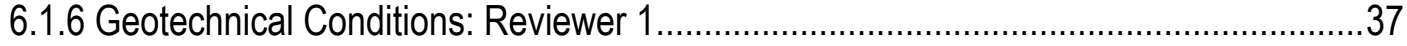

6.1.6 Geotechnical Conditions: Reviewer 2 ………………....................................38

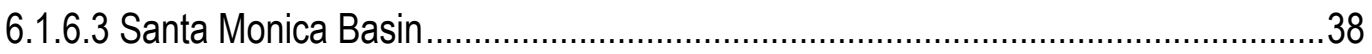

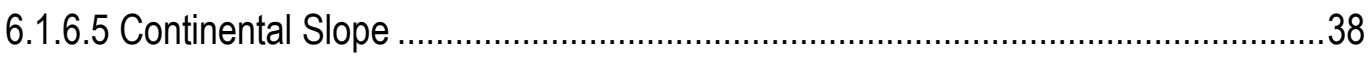

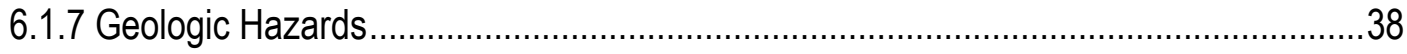

6.1.7.1 Surface Fault Rupture Hazard ....................................................................38

6.1.7.1 Surface Fault Rupture Hazard_Surface Fault Displacement Estimates and

6.1.7.2 Strong Ground Motion and Appendix M: Reviewer 1 .......................................39

6.1.7.1 Surface Fault Rupture Hazard - Surface Fault Displacement Estimates and 6.1.7.2

Strong Ground Motion and Appendix M: Reviewer 2 …...............................................41

6.1.7.1 Surface Fault Rupture Hazard—Surface Fault Displacement Estimates and

6.1.7.2 Strong Ground Motion and appendix M: Reviewer 3 .......................................4

6.1.7.2 and 6.4.2.5 Strong Ground Motions...............................................................46

6.1.7.3 Liquefaction and Lateral Spreading ..............................................................4

6.1.7.4 Sediment Transport and Mass Movement: Reviewer 1 ……….........................4

6.1.7.4 Sediment Transport and Mass Movement: Reviewer 2 ….................................48

6.1.7.5 (and 6.4.2.5) Volcanism............................................................................4

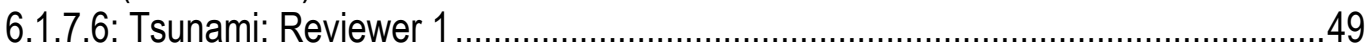

6.1.7.6 Tsunami: Reviewer 2 …………………………………………...... 50

6.1.7.7 Methane Hydrates, Shallow Gas and Seeps: Reviewer 1 ...............................51

6.1.7.7 Methane Hydrates, Shallow gas and Seeps: Reviewer 2 …..............................51

6.1.7.7 Methane Hydrates, Shallow Gas and Seeps: Reviewer 3 ….............................51

6.1.7.8 Onshore Geologic Hazards_Fault Zones and Seismicity ..................................52

6.1.7.8 Onshore Geologic Hazards-Areas Prone to Liquefaction ..................................52

6.1.7.8 Onshore Geologic Hazards - Landslide and Slope Instability: Reviewer 1 ...........52

6.1.7.8 Onshore Geologic Hazards_Landslide and Slope Instability: Reviewer 2 ..........52

6.1.7.8: Onshore Geologic Hazards_Areas Prone to Flooding …………….................52

6.1.7.9 Mineral Resources ...............................................................................52

6.1.7.10 Paleontological Resources ........................................................................54

6.3.1: GEO-18: Flooding of the Area Above the Buried Pipeline ......................................54

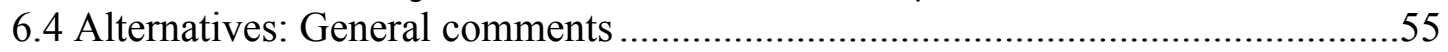


6.4.2.1 Geologic Setting: Reviewer 1 ......................................................................5

6.4.2.1 Geologic Setting: Reviewer 2 ….............................................................56

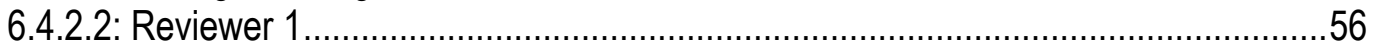

6.4.2.2 Structure and Seismicity: Reviewer 2 …...................................................56

6.4.2.3 Anticipated Conditions at the HDD for the AES Alternative: Reviewer 1 ..............56

6.4.2.3 Anticipated Conditions at the HDD for the AES Alternative: Reviewer 2 .............56

6.4.2.3 Anticipated Conditions at the HDD for the AES Alternative: Reviewer $3 \ldots \ldots \ldots \ldots . . .56$

See first reviewer's comments under section 6.1.3.1 ..............................................57

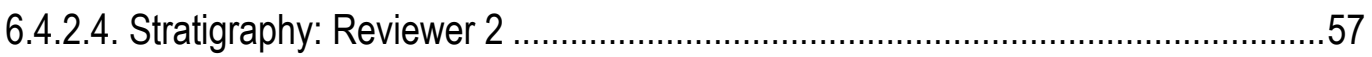

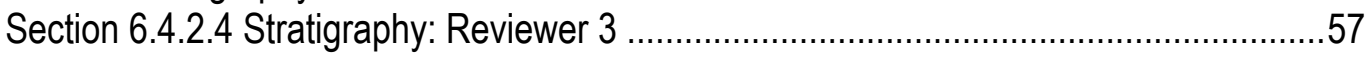

6.4.2.5 Geologic Hazards-Strong Ground Motions...................................................57

6.4.2.5 Geologic Hazards_-Surface Fault Rupture.....................................................57

6.4.2.5 Geologic Hazards_Liquefaction/Lateral Spreading ........................................57

6.4.2.5. Geologic Hazards-comment applies to both Liquefaction/Lateral Spreading and

Mass Movement sections ...................................................................................58

6.4.2.5 Geologic Hazards-Mass movement: slumps, slides, debris flows, turbidity

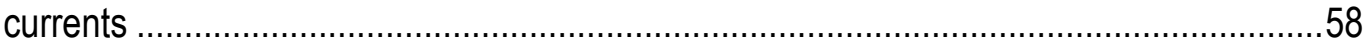

6.4.2.5 Geologic Hazards_-Volcanism: see section 6.1.7.5 ……………………........58

6.4.2.6 Mineral Resources..............................................................................58

6.4.2.7 Unique Geologic or Paleontological Resources................................................58

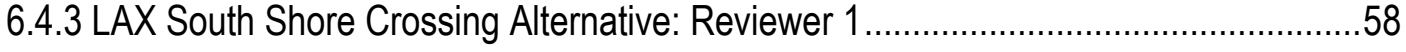

6.4.3 LAX South Shore Crossing Alternative: Reviewer 2 ………..................................58

6.4.3 - LAX South Shore Crossing Alternative: Reviewer 3 ……….................................59

6.4.4 Onshore Pipeline Alternatives: Reviewer 1 …………........................................59

6.4.4 Onshore Pipeline Alternatives: Reviewer 2 ……................................................59

6.4.4 Onshore Pipeline Alternatives: Reviewer 3 ………........................................59

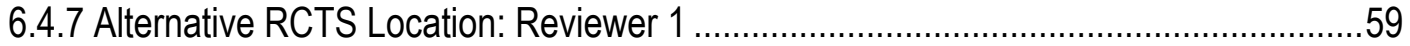

6.4.7 Alternative RCTS Location: Reviewer 2 ….......................................................59

Section 6.4.7 Alternative RCTS Location: Reviewer 3 ...................................................59

General Comments and Comments on Tables, Figures, Appendixes ..........................59

Table 6-1 Estimated Characteristics of Potential Seismogenic Sources ............................59

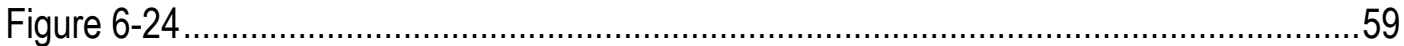

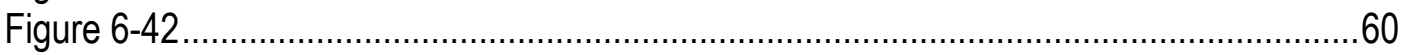

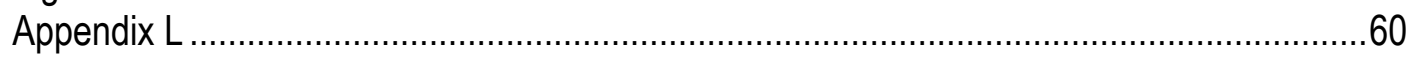

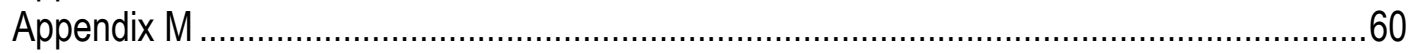

General Comment on Pipeline Location .................................................................60 


\section{Figures}

1. Map of proposed pipelines, geographic, and geologic features mentioned in this report. LAX is the Los Angeles International Airport, AES is the name of a company

2. Ratio of 1-Hz spectral acceleration (SA) from National Seismic Hazard Mapping Project (NSHMP) 2008 to NSHMP 2002 maps. Brown to red colors show increased hazard estimates in the 2008 maps, whereas yellow to blue colors show decreased hazard estimates. Offshore regions show significant increases in the 2008 estimate because of the fault hanging-wall effects included in the NGA relations.

\section{Tables}

1. Table of acronyms used in this report. 6 


\title{
Comments on Potential Geologic and Seismic Hazards Affecting Proposed Liquefied Natural Gas Site in Santa Monica Bay, California
}

\author{
By Stephanie L. Ross, Homa J. Lee, Tom E. Parsons, Larry A. Beyer, David M. Boore, \\ James E. Conrad, Brian D. Edwards, Michael A. Fisher, Arthur D. Frankel, Eric L. Geist, \\ Kenneth W. Hudnut, Susan E. Hough, Robert E. Kayen, Thomas D. Lorenson, Nicolas \\ Luco, Patricia A. McCrory, Mary L. McGann, Manuel Nathenson, Michael Nolan, Mark \\ D. Petersen, Daniel J. Ponti, Charles L. Powell, Holly F. Ryan, John C. Tinsley, Chris J. \\ Wills, Florence L. Wong, and Jingping Xu
}

(all authors are with the U.S. Geological Survey, except for Chris Wills, who is with the California Geological Survey)

\section{Executive Summary}

This report examines the geologic hazards that could affect the OceanWay Secure Energy Project, a proposal by Woodside Natural Gas to build liquefied natural gas (LNG) facilities offshore of the Palos Verdes Peninsula in southern California. These facilities would include a Deepwater Port (DWP), including submersible buoys, manifolds, and risers, which would be situated in 3,000 feet of water about 23 miles offshore. The DWP would be connected to onland facilities by 35 miles of pipeline, which would come onshore near the Los Angeles International Airport.

This report also examines the geologic hazards that could affect a proposed alternate location for the DWP that would be located approximately 20 miles offshore of Orange County, with the pipeline making landfall near the AES energy plant at Huntington Beach (note: AES is the company's name, not an acronym).

The U.S. Geological Survey (USGS) does not make any recommendation for or against the OceanWay Secure Energy Project. Instead, it is the USGS's goal to provide accurate and up-to-date geologic information for use by public policy officials involved in the approval process and for use by engineers in the design process if such a project does go forward.

As part of the Deepwater Port license application, Fugro West, Inc., has prepared a document discussing geologic hazards in the area, titled "Exhibit B Topic Report 6 Geological Resources" (Fugro West, Inc., 2007); hereafter, this will be called the "Geological Resources document." Our report summarizes the regional geologic hazards, reviews the Geological Resources document, and makes recommendations for future work to more fully assess the geologic hazards.

The LNG facility is proposed to lie in a region of known geologic hazards that include:

- Strong shaking from earthquakes: the estimated probability of a magnitude 6.5 or larger earthquake occurring in the next 30 years within about 30 miles of the 
proposed pipeline ranges from $16 \%$ at the pipeline's offshore end to $48 \%$ where it nears land (Petersen and others, 2008). Earthquakes of this size can cause damage over a large region, such as occurred as a result of the 1994 M 6.7 Northridge earthquake.

- Sea floor offsets by faulting during earthquakes: the proposed pipeline crosses at least two faults that reach the surface.

- Liquefaction: this occurs when earthquake shaking causes wet and loose sandy material to liquefy, leading to horizontal displacements as large as tens of feet. This can be especially damaging to buried utilities and unsupported foundations.

- Tsunamis: waves caused by sea floor displacement during local and distant earthquakes or submarine landslides. These waves can affect built structures on the ocean bottom and onshore.

- Sediment transport events: submarine landslides and mass movements of loose sediment and rock slurries (known as turbidity currents, debris flows, or hyperpycnal flows, depending on their specific causes and characteristics) could impact structures on the sea floor.

- Erosion or scouring: caused by sediment transport events, tsunamis, and storm waves, could expose sections of the pipeline that were expected to settle into soft sediments on the sea floor, possibly leaving sections of the pipeline unsupported (known as pipeline spanning).

- Shallow gas deposit venting: could lead to pipeline spanning and other disruption to the facility.

- Pipeline settling: variable settling of the pipeline into sediment of differing strength could cause deformation of the pipeline.

The regional geologic hazards and the Geological Resources document were reviewed by 27 scientists from the USGS and the California Geological Survey (CGS). Overall, the reviewers found that the Geological Resources document represents most of the geologic hazards in the project area. However, there are also some hazards not completely represented. We note that there are new consensus seismic hazard reports that have been released since the Geological Resources document was written. In some cases, as detailed throughout the rest of the report, additional scientific studies are recommended to improve geological hazard assessments.

New scientific assessments based on our recommendations will not necessarily reveal increased hazard. For example, the Geological Resources document calculates greater seismic hazard in the project area than do the updated National Seismic Hazard Maps (Petersen and others, 2008). Conversely, we make recommendations for more detailed assessment of hazards posed by tsunamis and sediment transport events because we believe that the impact of such events may be underrepresented in the Geological Resources document. This enhanced scientific information would provide a better basis for evaluating this application and for the engineering design of the project should it go forward. 


\section{Introduction}

In a letter to the U.S. Geological Survey (USGS) dated March 25, 2008, Representative Jane Harman (California $36^{\text {th }}$ district) requested advice on geologic hazards that should be considered in the review of a proposed liquefied natural gas (LNG) facility off the California coast in Santa Monica Bay. In 2004, the USGS responded to a similar request from Representative Lois Capps, regarding two proposed LNG facilities offshore Ventura County, Calif., with a report summarizing potential geologic and seismic hazards (Ross and others, 2004).

The proposed LNG Deepwater Port (DWP) facility includes single point moorings (SPMs) and 35 miles of underwater pipelines. The DWP submersible buoys, manifolds, and risers would be situated on the floor of the southern Santa Monica Basin, in 3,000 feet of water, about 23 miles offshore of the Palos Verdes Peninsula. Twin 24-inch diameter pipelines would extend northeastward from the buoys across the basin floor, up the basin slope and across the continental shelf, skirting north around the Santa Monica submarine canyon. Figure 1 provides locations of the project and geologic features. Acronyms are defined in table 1.

This facility is being proposed in a region of known geologic hazards that arise from both the potential for strong earthquakes and geologic processes related to sediment transport and accumulation in the offshore environment. The probability of a damaging earthquake (considered here as magnitude 6.5 or greater) in the next 30 years within about 30 miles $(50 \mathrm{~km})$ of the proposed pipeline ranges from $16 \%$ at the pipeline's offshore end to $48 \%$ where it nears land (Petersen, 2008). Earthquakes of this magnitude are capable of producing strong shaking, surface fault offsets, liquefaction phenomena, landslides, underwater turbidity currents and debris flow avalanches, and tsunamis.

As part of the DWP license application for the Woodside Natural Gas proposal in Santa Monica Bay (known as the OceanWay Secure Energy Project), Fugro West, Inc., had already prepared a document discussing geologic hazards in the area, titled "Exhibit B Topic Report 6 - Geological Resources" (Fugro West, Inc., 2007); hereafter, this will be called the "Geological Resources document." The USGS agreed to evaluate the information in the Geological Resources document regarding (1) proximity of active faults to the proposed project, (2) potential magnitude of seismic events from nearby faults, (3) thoroughness of the assessment of earthquake hazards in general, (4) potential hazards from ground rupture and strong shaking, (5) potential hazards from tsunamis, and (6) other geologic hazards including landslides and debris flows. Because two new earthquake probability reports were scheduled to be released in mid-April, 2008, by the USGS and the California Geological Survey (CGS), the USGS suggested a 6-month review period to enable a thorough incorporation of this new information.

Twenty-seven scientists from the USGS and the CGS reviewed various sections of the Geological Resources document. This report outlines our major conclusions. The appendix is a longer list of comments by these reviewers, grouped by section of the Geological Resources document. Before discussing our reviews, we first provide a brief overview of geologic hazards in the proposed site area. 
This report is a snapshot in time and any future work in the area will need to take into account ongoing research efforts. For example, USGS scientists collected seismic reflection data in the spring of 2008 to study the structure and seismic potential of several faults in the area. Their interpretations (Conrad and others, 2008a and 2008b) are too preliminary to be included in this report, but their final results, along with other researchers' studies in the project area, should be considered in any future work on the Deepwater Port project. 


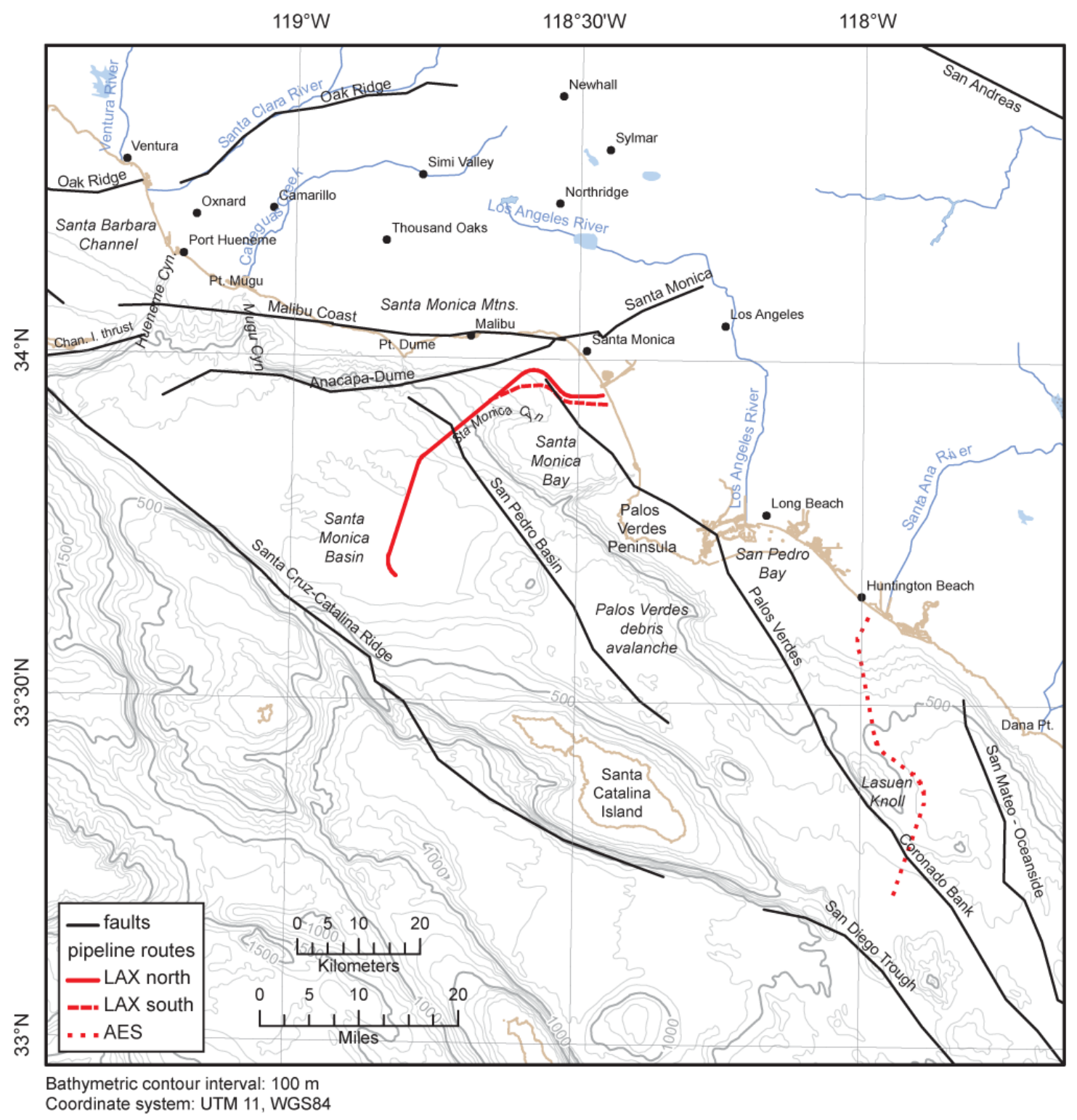

Figure 1. Map of proposed pipelines, geographic, and geologic features mentioned in this report. LAX is the Los Angeles International Airport; AES is the name of a company. 
Table 1. List of acronyms used in this report.

\begin{tabular}{|l|l|}
\hline AES & $\begin{array}{l}\text { AES Power Plant, Huntington Beach, Orange County (note: AES } \\
\text { is a company name and not actually an acronym). }\end{array}$ \\
\hline CDMG & California Division of Mines and Geology, now CGS \\
\hline CGS & California Geological Survey, formerly CDMG \\
\hline $\begin{array}{l}\text { Geological } \\
\text { Resources document }\end{array}$ & Exhibit B Topic Report 6 - Geological Resources \\
\hline DWP & Deepwater Port \\
\hline HDD & Horizontal Directional Drilling \\
\hline LAX & Los Angeles International Airport \\
\hline LNG & Liquefied Natural Gas \\
\hline MCE & NFPA Maximum Credible Earthquake \\
\hline NFPA & National Fire Protection Agency \\
\hline NGA & $\begin{array}{l}\text { Next Generation Attenuation (earthquake ground motion model } \\
\text { that relates the amount of ground motion to the distance from the } \\
\text { earthquake source and to the specific source and site conditions) }\end{array}$ \\
\hline NSHMP & National Seismic Hazard Mapping Project \\
\hline NTHMP & National Tsunami Hazard Mitigation Program \\
\hline OBE & NFPA Operating Basis Earthquake \\
\hline ODP & Ocean Drilling Project \\
\hline OES & California State Office of Emergency Services \\
\hline PSHA & Probabilistic Seismic Hazards Assessment \\
\hline SPM & Single Point Mooring \\
\hline SSE & NFPA Safe Shutdown Earthquake \\
\hline UCERF2 & Uniform California Earthquake Rupture Forecast version 2 \\
\hline USGS & U.S. Geological Survey \\
\hline WGCEP08 & Working Group on California Earthquake Probabilities, 2008 \\
\hline
\end{tabular}




\section{Scope of This Report}

Our report is limited to geologic hazard issues and other geological topics. No additional field studies or site-specific investigations were undertaken; this report is based on previously compiled, publicly available data. We have not attempted to review proposed engineering plans as this is beyond the scope of our expertise. Also, we assume that nongeological hazards to the pipeline, such as trawling or deep-line fisheries activities, dredging operations, and local dump sites, are covered elsewhere in the license application. Similarly, we assume that the effects of the pipeline on fisheries, potential submerged archeological sites, or biological communities such as those at cold-seeps are also considered elsewhere.

The USGS does not make recommendations as to whether or not specific projects, such as the proposed LNG facility in Santa Monica Bay, should be approved. Instead, the USGS serves to provide the best science information possible, and it is up to others to use this information to guide their policy decisions. For example, when considering the risks posed by strong shaking during earthquakes, the USGS provides estimates of the groundshaking hazard for any probability level, and engineers and public policy experts must decide on the appropriate probability level to be used in the design of a facility or project. This probability level is determined by the acceptable level of risk, which will vary depending on the consequences of structural failure. For example, the U.S. Nuclear Regulatory Commission now specifies a hazard level for nuclear power plants that has a probability 40 times stricter than the 2\% in 50-year hazard level used for many other purposes.

Although the USGS role in this process is limited to scientific issues, such information can lead to impressive mitigation of natural hazards. For example, the survival of the Trans-Alaska pipeline in the 2002 magnitude (M) 7.9 Denali earthquake was the result of careful engineering to meet stringent design specifications based on geologic studies done by the USGS, Woodward-Lundgren and Associates, and others in conjunction with the Alyeska Pipeline Service Company. The survival of the pipeline demonstrates the value of combining careful geologic studies of earthquake hazards with creative engineering in designing and protecting important infrastructure (Fuis and Wald, 2003).

\section{Overview of Geologic Hazards in the Proposed Area}

The important geologic hazards in this area are similar to those in the area covered in the report by Ross and others (2004). These include earthquakes, tsunamis, liquefaction, submarine landslides, debris flows, and turbidity currents (including hyperpycnal flows). These are defined and discussed below.

\section{Faults and Earthquakes}

The area of the proposed project, like all of southern California, is an active seismic area affected by both local faults and earthquakes and the shaking from distant earthquakes. All of these earthquakes are the result of large-scale Earth processes in which the Pacific Plate slides northwestward relative to the North American Plate at about 2 inches/year. This plate motion results in horizontal slip (primarily on the San Andreas "strike-slip" 
fault) as well as a component of compression that has created the series of east-west trending "thrust" faults with vertical motion that are responsible for the prominent mountain ranges and intervening valleys situated between Santa Monica and Santa Barbara. Although slower moving than the strike-slip faults of the San Andreas system, these numerous thrust faults account for more than half of the significant earthquakes that occurred in southern and central California during the past century, including the damaging and deadly 1971 M 6.6 San Fernando, 1994 M 6.7 Northridge, and 2003 M 6.5 San Simeon earthquakes.

Primary effects of earthquakes are permanent deformation of the ground, especially where an earthquake ruptures through to the Earth's surface, and the shaking produced by the earthquakes. This seismic shaking can also cause other geologic hazards such as landslides, liquefaction, debris flows, and turbidity currents.

The proposed pipeline route crosses active faults, where "active" is defined as having evidence of movement during the last about 11,000 years, known as the Holocene Epoch. These include two strike-slip faults, the San Pedro Basin Fault (Fisher and others, 2003) and the Palos Verdes Fault (Treiman and others, 1998), in addition to a presumed-active buried thrust fault beneath the shelf projection anticlinorium (a set of folded rocks). Thus, the permanent ground movement that could be caused by these faults needs to be considered.

Many earthquakes have struck this area since recorded history began around 1800 (http://www.data.scec.org/chrono_index/quakedex.html and references therein). The earliest reported earthquake in proximity to the study area was a November 22, 1800, event that caused damage in San Diego. The Rose Canyon Fault Zone offshore from Encinitas is suggested in CDMG (2000) as the probable source of this earthquake, the magnitude of which is estimated roughly as 6.5. A pair of large earthquakes struck southern California in December of 1812; the second of these, on December 21, is thought to have been approximately M7 and to have occurred in the Santa Barbara channel, although the location remains uncertain. Three other earthquakes caused at least light damage in San Diego in the $19^{\text {th }}$ century: an 1862 earthquake near San Diego $(\mathrm{M} \sim 6)$, the 1892 Laguna Salada earthquake in northern Baja California (M 7), and an 1894 earthquake (M 5.75) east of San Diego. It has not been possible to identify the faults that produced the 1862 or 1894 events.

In the $20^{\text {th }}$ century, a series of other nearby events have impacted this area. These include earthquakes in the Santa Barbara Channel in 1925 (M 6.3), 1941 (M 5.5), and 1978 (M 5.1), the 1933 M 6.4 Long Beach earthquake, the 1971 M 6.7 Sylmar earthquake, the 1973 M 5.2 earthquake offshore of Point Mugu (M 5.2), and the 1994 M 6.7 Northridge earthquake.

In 1857, a large earthquake (about M 8) ruptured 200 miles of the inland San Andreas Fault, from Cholame (near Paso Robles) to Wrightwood. This event, known as the great Fort Tejon earthquake, severely damaged Mission San Buenaventura. Although this event is far from the study area, it damaged structures throughout southern California and highlights the need to consider both local and distant earthquakes. 
The historical earthquake record in southern California only covers about 200 years, so potential seismic damage is not limited to what has recently been experienced at any given location. For example, the 1999 M 7.1 Hector Mine earthquake in the Mojave Desert of southern California occurred on a fault that geologists determined had not ruptured in more than 7,000 years (Rymer and others, 2002). Not only is the historical record limited, but so is our knowledge of active faults. The maximum magnitude of an earthquake is related to fault length: the longer the fault, the larger the potential earthquake can be (Wells and Coppersmith, 1994). As we learn more, connections between different faults are sometimes found (increasing total fault length and the sizes of potential earthquakes) that require changing earthquake hazards assessments.

\section{Earthquake Shaking}

Shaking from earthquakes is a function of earthquake magnitude, how far the site is from the earthquake, and special conditions such as the geologic structure at or near the site. Ground motions can be especially strong in sedimentary basins, in which seismic waves can be trapped and resonate with earthquake shaking. Shaking caused by earthquakes can also trigger liquefaction, debris flows, turbidity currents, landslides, and landslideinduced tsunamis.

Strong shaking is the primary hazard that causes damage from earthquakes, and the study area has been zoned with a high level of seismic shaking hazard. The goal of the USGS National Seismic Hazard Mapping Project (NSHMP) effort is to quantify the level of shaking that may occur with sufficient frequency that it should be considered in the development of building codes or the design of specific projects. For example, some of the NSHMP maps show the amount of earthquake shaking with a $2 \%$ chance of being exceeded in 50 years. Other probabilities are used depending on the purposes. For instance, in the National Fire Protection Agency (NFPA) codes considered in the license application for the proposed LNG DWP, a level of 10\% chance in 50 years is used for the Operating Basis Earthquake (OBE) through which one expects that the operation of the facilities would continue; that is, they would not need to be shut down. The NFPA codes use a level of $1 \%$ chance in 50 years for the Safe Shutdown Earthquake (SSE), which one expects would cause the facilities to be shut down but in a safe manner. At the Santa Monica site of this project, the USGS National Seismic Hazard Mapping effort estimates that the project would have to operate through shaking of $60 \%$ the force of gravity $(0.6 \mathrm{~g})$ to satisfy the OBE requirement and would have to be able to be shut down safely during shaking of $100 \%$ of the force of gravity $(1 g)$ to satisfy the SSE requirements.

\section{Liquefaction}

Liquefaction occurs in both onshore and offshore environments when earthquake shaking causes wet and loose sandy material to liquefy and lose almost all of its shear strength. Liquefaction during strong shaking can cause horizontal displacements as large as tens of feet and can be especially damaging to buried utilities and unsupported foundations. The venting of ground water as it is expelled from the liquefied sands can unevenly displace and tilt foundations, affecting both buried and surface structures. 


\section{Tsunamis}

Tsunamis can be generated by fault displacement generated by earthquakes, including large magnitude earthquakes distant from the site and local submarine earthquakes, or by submarine landslides near the site. In this area, a "worst-case" runup estimate of 40 feet $(12 \mathrm{~m})$ was adopted by Los Angeles County, and this was used by the National Tsunami Hazard Mitigation Program (NTHMP) through the California State Office of Emergency Services (OES) to prepare tsunami inundation maps for emergency planning purposes (Synolakis and others, 2002). More detailed tsunami studies should be done for purposes such as this project.

\section{Submarine Landslides}

The slopes of the southern California Borderland contain a large number of landslide deposits. The largest submarine landslide in the vicinity of the proposed LNG project is the Palos Verde Debris Avalanche. This slope has failed repeatedly in the same general area off the Palos Verdes Peninsula; a landslide of approximately 650 million cubic yards (Bohannon and Gardner, 2004) occurred about 7,500 years ago (Normark and others, 2004), but a smaller landslide may have occurred more recently, possibly 3,500 years ago. If another major landslide occurred in the same area in the future, the landslide material would not impinge on the LNG project, but it could generate a significant tsunami that would impact San Pedro and Santa Monica Bays. In addition, there are two smaller, buried landslides in Santa Monica Bay that extend about 900 feet from the base of the slope onto the floor of the Santa Monica basin that probably occurred about 10,000 years ago (Normark and Piper, 1998; Lee and others, 2004).

\section{Turbidity Currents and Debris Flows}

The delta of the Santa Clara River, a large pile of sediment fed by the Santa Clara River, is cut by five north-south trending submarine canyons on the delta slope, including Hueneme Canyon, which is farthest to the west and Mugu Canyon, the farthest to the east. Hueneme Canyon, the largest and most active of the five canyons, is the major conduit for mass movements of loose sediment and rock known as turbidity currents and debris flows (Normark and others, 1998, Piper and others, 1999). Most commonly, turbidity currents are produced when sediment in the head or sides of the canyon fails and disintegrates into dispersed sediment flows. However, turbidity currents can also be caused by hyperpycnal flows from rivers as discussed below.

Some river systems, including the Santa Clara River, carry substantial sediment in suspension during major flood events, and commonly this slurry of fresh river water and sediment is denser than sea water (Warrick and Milliman, 2003). When this occurs, gravity pulls the slurry downslope, forming high-speed turbulent flows known as hyperpycnal flows, which are a type of turbidity current (Mulder and Syvitski, 1995). Turbidity currents, especially on steeper slopes in submarine canyons, move with such speed and power that the only comparable on land processes are snow avalanches and the catastrophic volcanic flows that rush down the flanks of volcanoes during explosive eruptions. A turbidity current in the Laurentian Fan, off of Nova Scotia, broke many 
submarine telecommunications cables and is thought to have traveled at 45 miles per hour (see review of turbidity current processes in Normark and Piper, 1991). The Santa Monica Basin has less relief than the Laurentian Fan, so turbidity currents there would likely not reach the same speed. Reynolds (1987) documents a turbidity current event in the Santa Monica Basin about 100 years ago that transported more than a million cubic yards of sediment at speeds of 2 miles per hour. This event is suggested to have resulted from the southern California flood of 1884. A much larger turbidity current that transported more than 10 million cubic yards of sediment occurred about 200 years ago; it transported coarser (larger grain-size) sediment and its velocity must have been substantially greater (Malouta and others, 1981). This earlier event is suggested to have been generated as a result of sediment failure during the 1812 Santa Barbara earthquake (approximately M 7).

Although several canyons (Hueneme, Mugu, Dume, and Santa Monica) have discharged sediment onto the floor of Santa Monica Basin, Hueneme Canyon has been by far the major contributor and dominates basin floor deposition. Turbidity currents capable of transporting sand-sized sediment more than 35 miles from the Hueneme Canyon to the basin floor have occurred about every 200 years on average during the past 3,000 years (Normark and McGann, 2004). Triggered commonly by earthquakes and large storms, these flows are typically 150 feet thick (Piper and others, 2003). Several of the smaller canyons on the delta slope east of Hueneme Canyon are filled by deposits of past debris flows as much as 35 feet thick (Piper and others, 1999). These debris flows were probably generated by seismic shaking from nearby earthquakes.

Improved assessment of the hazards to the LNG project from these turbidity currents and debris flows will require research to answer the following questions. How stable are the deep channels cut into the submarine delta? How often do large storms, such as those related to El Niño events, create hyperpycnal flows? How often do earthquakes cause debris flows and turbidity currents? How often do submarine landslides cause debris flows and turbidity currents? How can pipeline designs protect against hazards from thick, energetic turbidity currents and debris flows?

\section{Overview of Our Comments on Fugro West, Inc., Document "Exhibit B Topic Report 6 - Geological Resources"}

In general, the USGS and CGS reviewers found the Geological Resources document to be a fairly thorough representation of the geologic hazards in the proposed LNG project area. Several reviewers found no significant deficiencies in the sections they reviewed. Many found the references to be outdated; some, but not all, of that deficiency was due to new information becoming available in reports written after the Geological Resources document was completed.

The Geological Resources document also discussed the proposed AES Alternative DWP, which would be located approximately 20 miles offshore of Orange County, with the pipeline making landfall near the AES energy plant at Huntington Beach (note: AES is the company's name, not an acronym). The discussion in the Geological Resources 
document of the AES Alternative DWP is less thorough. If this alternative is further considered, a more detailed, site-specific evaluation of the onshore and offshore geologic conditions and engineering properties would be needed; see the appendix for more details. Also, the location of the horizontal directional drilling (HDD) for the AES Alternative generally poses additional geologic hazards onshore, from possible liquefaction and flooding, as opposed to the proposed project location.

In the next section, we discuss the major issues regarding the proposed project that were, in the opinion of the USGS and CGS reviewers, either omitted or, in more cases, not evaluated fully enough in the Geological Resources document. These include issues regarding probabilistic seismic hazard analysis, tsunamis, liquefaction, pipeline settling and spanning, differential vertical uplift, storm waves, and several topics related to sediment movement. Following that we discuss new consensus reports regarding probabilistic seismic analysis that should be taken into account in future work dealing with the LNG project.

\section{Recommended Improvements for Future Analyses Based on Information that Existed When the Geological Resources Document was Prepared}

\section{Probabilistic Seismic Hazard Analysis}

Applying a probabilistic seismic hazard assessment (PSHA) to a project typically requires determining the level of hazard of concern. For instance, a project may be designed so that it will withstand an intensity of shaking that will be exceeded only $10 \%$ of the time in 50 years. A level of $10 \%$ in 50 years can also be described in terms of the average recurrence time for that intensity of shaking, known as a return period. For $10 \%$ in 50 years, the return period is 475 years. The PSHA results can be used to determine the intensity of shaking that corresponds to that level of hazard.

Because, according to the proposal, the design code that will be adopted by the U.S. Maritime Administration and the U.S. Coast Guard for LNG import facilities permitted in accordance with the Deepwater Port Act (U.S. Code Title 33, chapter 29) is unknown, "for perspective" the Geological Resources document authors have merely described the 2001 and 2006 National Fire Protection Agency (NFPA) requirements in Sections 6.1.4.5-6.1.4.7. According to the authors of the proposal, the design of onshore LNG facilities within the United States is conducted in accordance with the 2001 version of the NFPA 59A code. In 2006, the NFPA published an update of this code, as mentioned in the proposal. The most recent 2009 edition of the NFPA 59A code is not mentioned in the proposal.

Perhaps because, as stated in the proposal, "the actual design return periods for the DWP Project may vary from those required by NFPA," the proposal does provide the ground motions at the DWP for the return periods and respective exceptions associated with the NFPA Maximum Credible Earthquake (MCE), Operating Basis Earthquake (OBE), and Safe Shutdown Earthquake (SSE) ground motions. Thus, it is of primary importance that the applicable design code and/or design return periods for the DWP Project be 
determined. When doing this, recent changes to the design return periods for other types of projects such as building structures (for the upcoming 2009 editions of the NEHRP Recommended Provisions for Seismic Regulations for New Buildings and Other Structures) and nuclear power plants (as reflected in the 2007 U.S. Nuclear Regulatory Guide 1.208, A Performance-Based Approach to Define the Site-Specific Earthquake Ground Motion) should be considered for LNG facilities, including those to be permitted in accordance with the Deepwater Port Act. Changes to the former (for buildings) have been led by the USGS (for example, Luco and others, 2007).

Once the design return periods for the project are determined, for a project of this magnitude, the analysis should include a site-specific analysis of the amplification of seismic waves that occurs due to near-surface geologic structure and underlying sedimentary basins. This can be done by using site-specific profiles of shear-wave velocity to determine site response. It would also be desirable for the applicant to perform three-dimensional simulations of ground motions for certain earthquake scenarios to quantify the effects of basin surface waves at the proposed facilities and along the pipeline route. This topic will be revisited in the next section because new ground-motion attenuation relationships, the Next Generation Attenuation (NGA) relationships, published in February, 2008, have superseded the relationships used in the Geological Resources document.

\section{Tsunamis}

In terms of the impact analysis for offshore construction (Section 6.3.1), the applicant concludes that the DWP and offshore pipelines would not be significantly affected by tsunamis (subsection GEO-4). However, it should be verified that the unique wave mechanics of tsunamis have been fully taken into account. Although tsunami waves have occasionally been likened to storm-generated waves, unlike storm waves, the orbital motions for tsunamis involve the entire water column. Moreover, for a given wave height, currents associated with tsunamis are typically much stronger than those from storm-generated waves. Therefore, merely analyzing potential offshore wave height, as was done in the Geological Resources document, is not sufficient to fully assess the forces associated with tsunami waves that might affect deep-water pipelines and structures. Offshore structures in general are subject to inertial (currents) and drag forces from tsunamis; pipelines resting on the sea floor may also be affected by lift forces from tsunamis. A detailed analysis of the impact of tsunami waves on offshore structures and pipelines should be conducted, using wave characteristics (height and wavelength) specific to seismogenic and landslide-generated tsunamis. This analysis can then be used to determine if, for example, the pipeline design is adequately ballasted and anchored.

We could not discern what the source is for the "worst-case" tsunami scenario that the applicant used. The applicant should determine whether tsunamis generated by earthquakes along the Channel Islands, Oak Ridge, and Anacapa Dume thrust faults or landslide sources present the worst-case scenario. Similarly, we could not discern whether the applicant considered earthquake sources along the San Mateo and Oceanside thrust faults and landslides sources for the AES Alternative. For landslide sources, carrying out these studies of tsunami impact on the pipeline require careful geotechnical 
modeling of the detailed history of failure for a submarine landslide in order to make proper estimates of the tsunami-wave characteristics. Such geotechnical modeling does not appear to have been performed. Instead, the applicant appears to use the "worst-case" runup estimate of $12 \mathrm{~m}$ adopted by Los Angeles County and the inundation map (fig. 630 in the Geological Resources document), prepared by the National Tsunami Hazard Mitigation Program (NTHMP) through the California State Office of Emergency Services (OES) for emergency planning purposes. This allows the applicant to indicate that the horizontal directional drilling (HDD) entry (LAX North) is landward of the tsunami inundation zone and above the maximum runup elevation but does not allow them to make a full analysis of the offshore effects of the tsunami or to estimate uncertainties in the tsunami runup. At minimum, the impact analysis should include landslides having a wide range of reasonable failure histories to constrain tsunamigeneration parameters and, in general, provide an uncertainty estimate for tsunami runup and inundation. More detailed suggestions on how to perform this analysis are contained in the appendix.

\section{Liquefaction}

The discussion in the Geological Resources document of areas prone to earthquakeinduced liquefaction of wet and loose sandy material (sections 6.1.7.8 and 6.4.2.5) is not adequate on multiple accounts. (1) The pipeline will be trenched and backfilled along some portion of the route that is under water. One source of potential liquefaction hazard that is very serious is the poor quality and compaction of stated backfill material that will be used to cover the pipeline. There needs to be an evaluation of the potential for liquefaction of backfill material that will cause the pipeline to either sink or rise depending on its buoyancy at the time of an earthquake. (2) The Geological Resources document attempts to characterize liquefaction hazard offshore by evaluating sediment layering and grain size in cores that only sample the upper 8 meters beneath the sea floor. The potential for deeper sand layers to liquefy and compact during seismic shaking, thereby disrupting the DWP equipment or pipelines, needs to be considered. (3) The section in the document on liquefaction/lateral spreading hazards to the AES Alternative route focuses on the liquefaction and lateral spread hazard on shore but neglects offshore hazards on the shelf where potentially liquefiable sands that are fully saturated and noncohesive are present.

\section{Sediment Movement}

The Geological Resources document does not have a sufficiently complete analysis of several issues relating to sediment movement, which could adversely impact the pipeline and related LNG infrastructure. Issues related to potential sediment failures or sedimentladen fluid flow conditions include hyperpycnal flow, debris flows and turbidity currents, anthropogenic changes, cliff erosion, and scour from flooding and tsunamis. The following sections discuss each of these topics. 


\section{Hyperpycnal Flow}

Hyperpycnal flow is produced when the density of sediment-laden river water entering a basin is greater than the density of the sea water in the basin. The higher density river water can flow below the sea water, potentially eroding bottom sediments or impacting sea-floor structures. High-density hyperpycnal flow can transport sediment over great distances, up to hundreds of miles (Nakajima, 2006; Petter and Steel, 2006). Recent studies of continental margins suggest that small, high-yield rivers are capable of generating such flows, which "fundamentally alters our understanding of material flux from the continents to the oceans" (Addington and others, 2007).

The Geological Resources document states that Santa Clara River discharge is likely to produce sediment flows during major floods, episodes of storm surge or as a result of ground shaking during earthquakes. Flooding on Calleguas Creek, another major source of sediment to the area, is not discussed. Calleguas Creek discharges near the head of Mugu Canyon and thus has the potential for generating hyperpycnal flows, either during or after large storms, directly into the canyon head. Should high-density hyperpycnal flows result, such flows might either (1) create a direct hazard to pipelines in the Santa Monica Basin or (2) induce slope failures in the canyon (due to erosion and undercutting of the slopes) that could lead to much larger turbidity currents and increased hazard to the pipelines. Sediment mobilized during large wave events could conceivably also evolve into potentially hazardous sediment flows.

\section{Debris Flows and Turbidity Currents}

The Geological Resources document discusses turbidity currents in detail, but the possibility of debris flows moving out onto the floor of Santa Monica Basin needs to be more fully considered. Debris flows and turbidity currents are both types of mass gravity flows that are found in other fan systems. The difference is that debris flows can carry a greater density of material at higher speed (Bruschi and others, 2006). Thus, loading on a pipeline from a debris flow could be greater than loading from a turbidity current. The risk from debris flows, as well as from turbidity currents coming down the canyons and channels and out onto the pipeline area, needs to be evaluated.

We conclude that submarine sediment transport hazards should be further addressed. The Geological Resources document recognizes this point but does not suggest how this investigation will be done. Studies of the deposits left behind by past turbidity currents (known as turbidite deposits) could be used to estimate the characteristics of these flows. These characteristics could then be used to estimate the damage to the proposed facilities from similar events in the future. The Geological Resources document suggests that the pipeline will settle into the soft sea floor and that this will protect it to some degree from turbidity currents. This may not be sufficient because the turbidity currents could erode the soft sediment and expose the pipeline to damage. Thus, as part of the evaluation of the effects of debris flows and turbidity currents, it is important to address the erosive susceptibility of the soft sediment in central Santa Monica Basin, as well as the potential for such sediment flows to impact these distant reaches from the heads of the canyon-fan 
systems. Evaluating the effects of future debris flows and turbidity currents is difficult, and thus consequences of a pipeline rupture should also be evaluated.

\section{Anthropogenic Changes}

The Geological Resources document analyzed sediment history using cores that include one from the Ocean Drilling Program (ODP) that represents a long time series of depositional events. However, there have been anthropogenic changes in the sediment path that imply that the recent past and the future may be different from the distant past. Over geologic history, Hueneme Canyon has been more active than Mugu Canyon. However, piping systems presently bypass sand around the head of Hueneme Canyon, and much of this bypassed sand may move into the head of Mugu Canyon. This change in sediment loading could affect the stability of Mugu Canyon sediment and could lead to an anthropogenically influenced slope failure down Mugu Canyon. Sediment transport events associated with such a failure could be of a different nature than those represented by deposits in the ODP core and thus might have different characteristics (such as frequency and thickness) than those described in the Geological Resources document. It would be useful to evaluate how much sediment is moving through Mugu Canyon and to further evaluate the risk of sediment flow induced failure of the pipeline, especially considering anthropogenic changes.

\section{Coastal Bluff Erosion}

The Geological Resources document does not evaluate the potential for coastal bluff and dune erosion or slumping, processes which could create direct hazards to the pipelines where they come on shore.

\section{Scour}

Scour is erosion, or the removal of sediment, by moving water such as floods or tsunamis. To account for this process, more investigation should be done to provide an indication of how deeply the pipeline would need to be buried to avoid potential effects from scour by strong submarine bottom currents. Even a relatively simple analysis of potential scour depths everywhere the pipeline transverses the one-percent flood zone would be helpful (for more technical detail, see appendix, section 6.3.1, GEO-18).

Near shore, the pipeline is emplaced by horizontal directional drilling (HDD). It would be useful to verify that the scour depth from the worst-case tsunami is less than the depth of the pipeline where emplaced by HDD.

\section{Updated References}

Some of the references cited are outdated. Newer references that may bear on sediment transport and depositional environments in Santa Monica Bay include Alexander and Venherm (2003), Edwards and others (1996), Edwards and others (2003), Noble and Xu (2003), Romans (2008), Sommerfield and Lee (2004) and Warrick and others (2008). 


\section{Deformation Due to Pipeline Settling, Sand Waves, and Petroleum Fields}

The Geological Resources document anticipates that the pipelines will settle into the softer stretches of the sea floor and "bury themselves", but the report does not comment on how deep in the sediment column they expect the pipeline to settle. As discussed above, it is important to estimate how well this settling will protect the pipeline from scour due to hyperpycnal flow, debris flows and turbidity currents, flooding, and tsunamis. Future analyses should also evaluate the potential for differential settlement where the pipelines cross sea floor of variable hardness or whether the resultant differential stresses might affect the integrity of the pipelines. Another issue in the Geological Resources document is the potential for sand waves migrating across the shelf or how intermittent burial and exhumation by such migration might affect the integrity of the pipelines. Also, where the onshore portion of the pipelines cross or skirt active petroleum fields, there is the potential for differential ground subsidence and future analyses should address whether the resultant differential stresses might affect the integrity of the pipelines.

\section{Pipeline Spanning}

The pipeline will be supported in many places by sea-floor sediments. Pipeline spanning is a situation in which a section of the pipeline is not supported and this can cause serious problems. One scenario that could lead to pipeline spanning is if shaking during an earthquake causes very-near surface shallow gas deposits to become unstable and vent, which could in turn lead to a slumping of sediment that supports the pipeline. Scour resulting in pipeline spanning is also possible. Pipeline spanning could also prevent the pipeline from burying itself as expected. The Geological Resources document mentions these problems and future analyses should emphasize these important potential hazards.

\section{Storm Waves}

The report does not evaluate the impact of storm waves on the proposed pipelines where they cross the inner shelf (that is, 30 to 100 feet water depth) seaward of the portion intended to be buried using horizontal directional drilling. This needs to be considered.

\section{Recommended Improvements for Future Analyses Based on New Consensus Reports-Probabilistic Seismic Hazard Analysis}

Significant updates to the earthquake hazard assessment in California have been published during 2008, including a new version of the USGS National Seismic Hazard Mapping Project (NSHMP, 2008) maps and a new earthquake probability forecast known as the Uniform California Earthquake Rupture Forecast version 2 (UCERF2) from the Working Group on California Earthquake Probabilities (WGCEP, 2008). The new NSHMP mapping combines the UCERF2 earthquake probabilities with new models of how much shaking is produced by earthquakes. These new shaking models are known as the Next Generation Attenuation (NGA) relations. These changes have some significant effects on hazard assessment including: (1) there is often increased motion on the hanging wall of reverse and normal faults, and (2) intermediate- to long-period median 
ground motion estimates are reduced compared to previous models ( $\sim 25 \%$ near some of the major faults such as the San Andreas). Figure 2 highlights some of these effects, expressed as a ratio between the 2008 and 2002 NSHMP estimates.

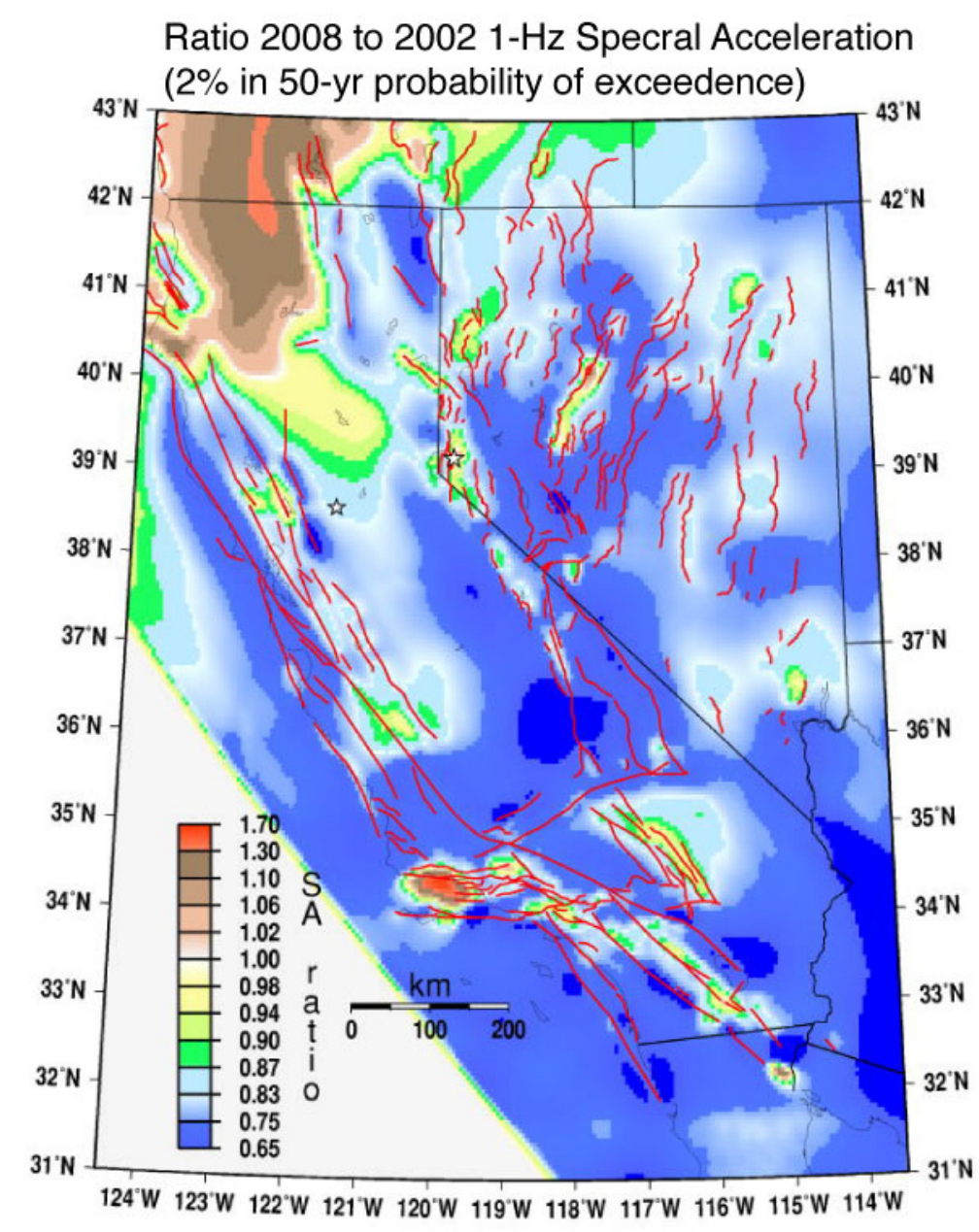

Figure 2. Ratio of 1-Hz spectral acceleration (SA) from National Seismic Hazard Mapping Project (NSHMP) 2008 to NSHMP 2002 maps. Brown to red colors show increased hazard estimates in the 2008 maps, whereas yellow to blue colors show decreased hazard estimates. Offshore regions show significant increases in the 2008 estimate because of the fault hanging-wall effects included in the Next Generation of Attenuation (NGA) relations.

We recommend that the hazard assessment provided in the Geological Resources document be compared for consistency with the NSHMP 2008 results. Ideally a ratio grid for the regions of interest similar to that of figure 2 would be produced. Further, because the Whittier-Elsinore and San Andreas Faults are discussed in the Geological Resources 
document, the WGCEP (2008) updated time-dependent probabilities for those faults should be considered.

In the following paragraphs we discuss the specific changes due to the new fault rupture forecasts (UCERF2) and the new ground-motion attenuation relationships (NGA) and how they may affect new results and could be used in future analyses for this project.

In developing source models for the probabilistic seismic hazard analysis (PSHA), the Geological Resources document used previously developed fault models in developing its model, including:

- Southern California Earthquake Center (SCEC) Community Fault Model Version 2.5 (Shaw and others, 2004). This reference provides detailed geometry of faults, but not slip rates, so it must be combined with other data for use in PSHA;

- Revised 2002 California Probabilistic Seismic Hazard Assessment (Cao and others, 2003). This model incorporates the 1996 USGS-CGS seismic hazard model and revisions for the 2002 model;

- CGS Fault Model for FRISKSP and EQFAULT (Blake, 2004). This is largely an attempt to reproduce the input and results of the 2002 USGS-CGS seismic hazard model; and

- Probabilistic Seismic Hazard Analysis for Southern California Coastal Facilities (Savy and Foxall, 2003).

These models and input values were considered in the development of the 2008 USGSCGS seismic hazard model. Because the Geological Resource document did not have the benefit of the revisions that were being done at CGS and USGS at the same time its authors were preparing their model, the results are not the same. In general, the Geological Resource document has included more faults and included slip rates for more faults than were included in the 2008 USGS-CGS seismic hazard model. In several cases, the Geological Resource document has included slip rate values for faults in the SCEC Community Fault Model that were not found to be sufficiently well documented for inclusion in the USGS-CGS 2008 seismic hazard model. The net effect of these additional slip rate values is that the Geological Resource document model has more faults that have higher activity rates near the proposed facilities than the USGS-CGS 2008 model. This appears to result in a seismic hazard model that suggests stronger ground motion values for most offshore areas than the USGS-CGS 2008 model. The appendix (section 6.1.7.1) contains a fault-by-fault comparison of the differences we note between the USGS-CGS 2008 model and that used in the Geological Resource document.

It should be noted that the addition of these estimated slip rates for a number of faults offshore of southern California results in additional right-lateral shear across the region. In developing the 2008 USGS-CGS hazard model, used by the WGCEP and the NSHMP, the overall right-lateral shear rates from faults was compared with rates from geodetic measurements and from long term tectonic plate motions. There was good correspondence between the total of fault slip rates in that model and both the overall geodetic rate and the long-term plate rate. It appears that the model developed in the Geological Resource document includes at least $6 \mathrm{~mm} / \mathrm{yr}$ of right-lateral shear not 
included in the 2008 model. This additional right-lateral shear may result in the Geological Resource document model being inconsistent with the geodetic and tectonicplate motion rates and may result in a higher than correct rate of earthquakes being used in their seismic hazard assessment.

In addition to the differences in slip rates in the Geological Resource document model, when compared with the USGS-CGS 2008 model, there are differences in the potential for combinations of faults and fault segments in the models. Many faults in the Geological Resource document model have the potential for earthquakes that rupture multiple segments or segments of adjacent faults. This concept was adopted and applied to a few faults by the WGCEP (2008). There are several cases where the Geological Resource document model includes the potential for multisegment rupture but the USGSCGS 2008 model does not. There are two major fault zones where the USGS-CGS model allows for multisegment rupture but the Geological Resource document model does not. These are the Newport Inglewood-Rose Canyon Fault Zone, where the USGS-CGS model includes the potential for a rupture of the entire zone in a M7.5 earthquake, and the Palos Verdes-Coronado Bank Fault Zone, where the USGS-CGS model includes the potential for a rupture of the entire zone in a M7.7 earthquake. These differences reflect both the Geological Resource document and the WGCEP recognizing the same issuethat multisegment earthquakes need to be considered in a PSHA - and implementing slightly different solutions to the problem. If the WGCEP results are adopted in future analyses for this project then the results will be consistent with the consensus reports of the scientific community. The next section contains further discussion of these issues based on newly acquired data that was not available to the WGCEP.

The probabilistic seismic hazard assessment (PSHA) done for this preliminary study used four ground-motion attenuation relations: Abrahamson and Silva (1997), Boore and others (1997), Campbell and Bozorgnia (2003), and Sadigh and others (1997). This assessment is described in section 4.3.3 of the Appendix to the PSHA section of the Geological Resources document. Attenuation relations relate the amount of ground motion to the distance from the earthquake source and to the specific source and site conditions. With the recent release of the Next Generation of Attenuation (NGA) relations (published in Earthquake Spectra, February 2008), the older attenuation relations have been superseded. The NGA relations should be used in the PSHA. It is critical that this PSHA incorporate the appropriate Vs30 (30 m averaged shear-wave velocity) for the sites of interest, as well as basin-depth terms, when implementing the NGA relations. It is also important that the PSHA includes the proper range of depth to top of rupture, focal mechanism type, and hanging wall terms, as appropriate. The applicant should also be aware that the NGA relations may not capture all of the epistemic uncertainty (uncertainty due to a lack of knowledge) in ground motions and should consider adding additional epistemic uncertainty. This epistemic uncertainty affects the mean hazard curves. Additional epistemic uncertainty to the NGA relations was included in the 2008 USGS National Seismic Hazard Maps (Petersen and others, 2008). 
It would be best if the applicant used site-specific profiles of shear-wave velocity to determine site response. It would also be desirable for the applicant to perform threedimensional simulations of ground motions for certain earthquake scenarios to quantify the effects of basin surface waves at the proposed facilities and along the pipeline route.

Taking both the differences in the fault model and the attenuation relationships into account, we note the following differences between the Geological Resource document results and those from the NSHMP (2008). Plots demonstrating these differences are shown in the appendix (section 6.1.7.1).

1. Proposed ground motions for Santa Monica DWP site at $118.808 \mathrm{~W}, 33.698 \mathrm{~N}$ appear to be higher than the new 2008 USGS hazard model (ground motions) for all periods checked. For operating-basis earthquake spectral acceleration (OBE $\mathrm{Sa}$ ), the USGS ground motions are generally 27 to $41 \%$ lower. For safe-shutdown earthquake spectral acceleration (SSE Sa), the USGS ground motions are generally 7 to $33 \%$ lower.

2. Ground motions for Santa Monica DWP are lower than ground motions at a site directly over the Palos Verdes fault at site $118.56 \mathrm{~W}, 33.97$ N. USGS ground motions are typically as much as $15 \%$ higher for OBE Sa and 35 to $37 \%$ higher for the SSE Sa ground motions.

3. Analysis by the USGS of which faults contribute to the hazard at this site contain contributions from the San Andreas Fault, whereas the analysis in the Geological Resources document does not show these contributions from distant sources, such as the San Andreas Fault.

In addition to the analysis of ground-motions, the seismic hazard assessment done in the Geological Resources document considers the hazard due to fault ruptures of the Earth's surface. Their assessment is based on the Youngs and others (2003) probabilistic methodology for fault displacement hazard and uses the empirical relationship for maximum fault displacement of Wells and Coppersmith (1994). Parameters applied to the analysis include a Palos Verdes north section and north and south sections together which result in M 6.6 and 7.3 earthquake ruptures, respectively. In contrast, the new WGCEP 08 model allows for M 7.7 (+/- 0.2$)$ earthquakes on this fault. Parameters applied to the analysis of the San Pedro Fault segments also range from about M 6.5 to 7.3. The San Pedro Fault is not included in the new WGCEP 08 model. The Geological Resource document probabilistic fault displacement hazard assessment results yield displacements from 0 to 23 feet. The Wells and Coppersmith relationship for an M 7.7 earthquake yields a maximum displacement of 23 feet. If one considers a 7.9 event, the maximum displacement would be about 33 feet. The 2002 M 7.9 Denali earthquake (strike-slip) in Alaska resulted in many 16 foot or greater displacements, some as much as 30 feet. The proposed pipeline crossing is near the end of the fault so the displacements would probably be less than the maximum. This suggests that the analysis in the Geological 
Resources document is reasonable, but future analyses of fault rupture hazard should utilize the WGCEP 08 model.

It is important that future analyses resolve these discrepancies by adopting the new consensus reports. If future analyses differ from these consensus reports, then it is important for the authors to justify the differences and show the impact of these differences on their results.

\section{Additional Suggestions for Further Studies}

The previous sections have discussed many studies that could be undertaken to enhance knowledge of geologic hazards in the proposed project area. Here we present two additional ones.

Gaps in the present sets of data are identified in the Geological Resource document, as are the need for more thorough investigations, such as in the high-wave-energy nearshore where the pipelines will be placed across the shoreline using HDD technology. In this area, immediately offshore of the beach, there are no detailed seismic-reflection data nor is there much if any geotechnical data. Further studies will be needed to develop detailed designs, and the consultants acknowledge this. We agree with the Geological Resource document's recommendation that additional subsurface explorations be performed in the offshore using rotary drilling techniques and piston cores which would support engineering design of the pipeline alignment in the offshore region.

We suggest studies of shallow gas and gas hydrates along the proposed pipeline routes because venting of such gases could lead to pipeline spanning. This would involve a series of seismic-reflection lines and piston cores to determine the presence of gas related hazards.

\section{Acknowledgments}

This document was greatly improved through reviews by Ruth Harris and Samuel Johnson. Edits by James Hendley, II, Jane Ciener, Carolyn Donlin, and Helen Gibbons added additional clarity. We thank Stephen Harmsen for providing probability calculations and Michael Diggles for formatting and supporting the web version of the report. 


\section{References}

Abrahamson, N.A., and Silva, W.J., 1997, Empirical response spectral attenuation relations for shallow crustal earthquakes: Seismological Research Letters, v. 68, no. 1.

Addington, L.D., Kuehl, S.A., and McNinch, J.E., 2007, Contrasting modes of shelf sediment dispersal off a high-yield river-Waiapu River, New Zealand: Marine Geology, v. 243, p. 18-30.

Alexander, C., and Venherm, C., 2003, Modern sedimentary processes in the Santa Monica, California continental margin - Sediment accumulation, mixing and budget: Marine Environmental Research, v. 56, p. 177-204.

Bohannon, R.G., and Gardner, J.V., 2004, Submarine landslides of San Pedro escarpment, southwest of Long Beach, California: Marine Geology, v. 203, p. 261-268.

Boore, D.M., Joyner, W.B., and Fumal, T.E., 1997, Equations for estimating horizontal response spectra and peak acceleration from western North American earthquakes-A summary of recent work: Seismological Research Letters, v. 68, no. 1.

Bruschi, R., Bughi S., Spinazzè M., Torselletti E., and Vitali L., 2006, Impact of debris flows and turbidity currents on seafloor structures: Norwegian Journal of Geology, v. 86, p. 317-337.

Campbell, K.W., and Bozorgnia, Y., 2003, Updated ground-motion (attenuation) relations for western and eastern North America: Bulletin of Seismological Society of America, v. 93, no. 1.

Cao, T., Bryant, W.A., Rowshandel, B., Branum D., and Wills, C.J., 2003, The revised 2002 California probabilistic seismic hazard maps, June 2003: Available through the California Geological Survey Web Page [http://www.consrv.ca.gov/cgs/rghm/psha/].

Conrad, J.E., Ryan, H.F., Paull, C.K., Caress, D.W., and Sliter, R.W., 2008a, The Palos Verdes and Coronado Bank fault zones, inner continental borderland, southern California - Do they connect?: Geological Society of America Abstracts with Programs, 2008 Annual Meeting, Houston, Texas.

Conrad, J.E., Ryan, H.F., and Sliter, R.W., 2008b, New high-resolution seismic reflection data show an active fault linking the San Diego Trough and San Pedro Basin fault zones, inner Continental Borderland, southern California: Geological Society of America Abstracts with Programs, 2008 Annual meeting, Houston, Texas,

Edwards, B.D., Dartnell, P. and Chezar, H., 2003. Characterizing benthic substrqates of Santa Monica Bay with seafloor photography and multibeam sonar imagery: Marine Environmental Research, v. 56, p. 47-66.

Edwards, B.D., Field, M.E., and Kenyon, N.H., 1996, Morphology of small submarine fans, inner California continental borderland, in Gardner, J.V., Field, M.E., and Twichell, D.C., eds.: Geology of the United States seafloor-The view from GLORIA, Cambridge University Press, p. 235-249.

Fisher, M.A., Normark, W.R., Bohannon, R.G., Sliter, R.W., and Calvert, A.J., 2003, Geology of the continental margin beneath Santa Monica Bay, southern California, from seismic-reflection data: Bulletin of the Seismological Society of America, v. 93, p. 1955-1983. 
Frankel, A.D., Petersen, M.D., Mueller, C.S., Haller, K.M., Wheeler, R.L., Leyendecker, E.V., Wesson, R.L., Harmsen, S.C., Cramer, C.H., Perkins, D.M., and Rukstales, K.S., 2002, Documentation for the 2002 Update of the national seismic hazard maps, U.S. Geological Survey Open-File Report 02-420, 33 p. [http://pubs.usgs.gov/of/2002/ofr-02-420/].

Fugro West, Inc., 2007, Woodside Natural Gas Inc., OceanWay Secure Energy Liquefied Natural Gas Deepwater Port license application; report 6, geological resources parts 1-10: Federal Register, v. 72, no. 173, p. 5148851489, document USCG-2006-26844

[http://www.regulations.gov/fdmspublic/component/main?main=Docume ntDetail\&o=090000648035e1de].

Fuis, G.S., and Wald, L.A., 2003, Rupture in south-central Alaska-The Denali Fault earthquake of 2002, U.S. Geological Survey Fact Sheet, 014-03, 4 p. [http:/pubs.usgs.gov/fs/2003/fs014-03].

Lee, H.J., Normark, W.R., Fisher, M.A., Greene, H.G., Edwards, B.D., and Locat, J., 2004, Timing and extent of submarine landslides in southern California: Offshore Technology Conference paper number 16744, Houston, Texas.

Luco, N., Ellingwood, B.R., Hamburger, R.O., Hooper, J.D., Kimball, J.K., and Kircher, C.A., 2007, Risk-targeted versus current seismic design maps for the conterminous United States: Proceedings of the 2007 Structural Engineers Association of California (SEAOC) Convention, p. 163-175.

Malouta, D.N., Gorsline, D.S., and Thornton, S.E., 1981, Processes and rates of recent (Holocene) basin filling in an active transform margin-Santa Monica Basin, California continental borderland: Journal Sedimentary Petrology, v. 51, p. 10771096.

Mulder, T., and Syvitski, J.P.M., 1995, Turbidity currents generated at mouths of rivers dureing exceptional discharges to the world oceans: Journal of Geology, v. 103, p. 285-299.

Nakajima, T., 2006, Hyperpycnites deposited $700 \mathrm{~km}$ away from river mouths in the central Japan Sea: Journal of Sedimentary Research, v. 76, p. 60-73.

Noble, M., and Xu, J.P., 2003, Observations of large-amplitude cross-shore internal bores near the shelf break, Santa Monica Bay, CA: Marine Environmental Research, v. 56, p. 127-150.

Normark, W.R., and McGann, M., 2004, Late Quaternary deposition in the inner basins of the California continental borderland; part A, Santa Monica Basin: U.S. Geological Survey Scientific Investigations Report 2004-5183.

Normark, W.R., McGann, M., and Sliter, R.W., 2004, Age of Palos Verdes submarine debris avalanche, southern California: Marine Geology, v. 203, 247-259.

Normark, W.R., and Piper, D.J.W., 1991, Initiation processes and flow evolution of turbidity currents-Implications for the depositional record, in Osborne, R.H., ed., From shoreline to abyss: Society of Sedimentary Geology Special Publication No. 46, p. 207-230.

Normark, W.R., and Piper, D.J.W., 1998, Preliminary evaluation of recent movement on structures within the Santa Monica Basin, offshore southern California, U.S. Geological Survey Open-File Report 98-518, 60 p. 
Normark, W.R., Piper, D.J.W., and Hiscott, R.N., 1998, Sea level controls on the textural characteristics and depositional architecture of the Hueneme and associated submarine fan systems, Santa Monica Basin, California: Sedimentology, v. 45, p. 53-70.

Petersen, M.D., Frankel, A.D., Harmsen, S.C., Mueller, C.S., Haller, K.M., Wheeler, R.L., Wesson, R.L., Zeng, Y., Boyd, O.S., Perkins, D.M., Luco, N., Field, E.H., Wills, C.J., and Rukstales, K.S., 2008, Documentation for the 2008 update of the United States national seismic hazard maps: U.S. Geological Survey Open-File Report 2008-1128, 61 p. [http://pubs.usgs.gov/of/2008/1128/].

Petter, A.L., and Steel, R.J., 2006, Hyperpycnal flow variability and slope organization on an Eocene shelf margin, Central Basin, Spitsbergen: American Association of Petroleum Geologists, Bulletin, v. 90, p. 1451-1472.

Piper, D.J.W., Hiscott, R.N., and Normark, W.R., 1999, Outcrop-scale acoustic facies analysis and latest Quaternary development of Hueneme and Dume submarine fans, offshore California: Sedimentology, v. 46, p. 47-48.

Piper, D.J.W., Normark, W.R., and McGann, M., 2003, Variations in accumulation rate of late Quaternary turbidite deposits in Santa Monica Basin, offshore southern California: Eos Transactions of the American Geophysical Union, v. 84, no. 46, Fall Meeting Supplement, Abstract OS52B-0916.

Reynolds, S., 1987, A recent turbidity current event, Hueneme fan, CaliforniaReconstruction of flow properties: Sedimentology, v. 34, p.129-137.

Romans, Brian, 2008, Controls on distribution, timing, and evolution of turbidite systems in tectonically active settings-Upper Cretaceous Tres Pasos Formation, southern Chile, and Holocene Santa Monica Basin, offshore California: Palo Alto, Calif., Stanford University, Ph.D. dissertation.

Ross, S.L., Boore, D.M., Fisher, M.A., Frankel, A.D., Geist, E.L., Hudnut, K.W., Kayen, R.E., Lee, H.J., Normark, W.R., and Wong, F.L., 2004, Comments on potential geologic and seismic hazards affecting coastal Ventura County, California: U.S. Geological Survey Open-File Report 2004-1286, 20 p. [http://pubs.usgs.gov/of/2004/1286/].

Rymer, M.J., Seitz, G.G., Weaver, K.D., Orgil, A., Faneros, G., Hamilton, J.C., and Goetz, C., 2002, Geologic and paleoseismic study of the Lavic Lake fault at Lavic Lake playa, Mojave Desert, southern California: Bulletin of the Seismological Society of America, v. 92, p. 1577-1591.

Sadigh, K., Chang, C.Y., Egan, J.A., Makdisi, F., and Youngs, R.R., 1997, Attenuation relationships for shallow crustal earthquakes based on California strong motion data, Seismological Research Letters, v. 68, no. 1, p. 180-189.

Savy, J., and Foxall, B., 2003, Probabilistic seismic hazard analyses for southern California coastal facilities: Hazards Mitigation Center, Lawrence Livermore National Laboratory, UCRL-TR-204215, p. 94.

Shaw, J., Plesch, A., and Planansky, G., 2004, SCEC Community fault model, Harvard University and Southern California Earthquake Center (SCEC): Department of Earth and Planetary Sciences [http://structure.harvard.edu/cfm, last updated January 4, 2004].

Sommerfield, C.K., and Lee, H.J., 2004. Across-shelf sediment transport since the last glacial maximum, southern California margin: Geology, v. 32, p. 345-348. 
Synolakis, C.E., Borrero, J., and Eisner, R., 2002, Developing inundation maps for southern California, American Society of Civil Engineers Conference Proceedings 258, 73 [doi:10.1061/40605(258)73].

Treiman, Jerome, and Lundberg, Matthew, compilers, 1998, Fault number 128c, Palos Verdes fault zone, San Pedro Shelf section, in Quaternary fault and fold database of the United States: U.S. Geological Survey

[http://earthquakes.usgs.gov/regional/qfaults, last accessed 10/15/2008 05:49 $\mathrm{PM}]$.

Warrick, J.A., and Milliman, J.D., 2003, Hyperpycnal sediment discharge from semiarid southern California rivers-Implications for coast sediment budgets: Geology, v. 31, p. 781-784.

Warrick, J.A., Xu, J.P., Noble, M.A., and Lee, H.J., 2008, Rapid formation of hyperpycnal sediment gravity currents offshore of a semi-arid California river: Continental Shelf Research, v. 28, p. 991-1009.

Wells, D.L., and Coppersmith, K.J., 1994, New empirical relationships among magnitude, rupture length, rupture width, rupture area and surface displacement: Bulletin of the Seismological Society of America, v. 84, p. 974-1002.

2007 Working Group on California Earthquake Probabilities, 2008, The uniform California earthquake rupture forecast, version 2 (UCERF 2): U.S. Geological Survey Open-File Report 2007-1437 and California Geological Survey Special Report 203 [http://pubs.usgs.gov/of/2007/1437/]. version 1.1.

Youngs, R.R., Arabasz, W.J., Anderson, R.E., Ramelli, A.R., Ake, J.P., Slemmons, D.B., McCalpin, J.P., Doser, D.I., Fridrich, C.J., Swan, F.H., III, Rogers, A.M., Yount, J.C., Anderson, L.W., Smith, K.D., Bruhn, R.L., Knuepfer, P.L.K., Smith, R.B., DePolo, C.M., O'Leary, D.W., Coppersmith, K.J., Pezzopane, S.K., Schwartz, D.P., Whitney, J.W., Olig, S.S., and Toro, G.R., 2003, A methodology for probabilistic fault displacement hazard analysis (PFDHA): Earthquake Spectra, v. 19, p. 191-219. 


\section{Appendix-Reviewers' Comments}

Twenty-seven reviewers, all authors of this report, commented on different sections of the document written by Fugro West, Inc., titled "Exhibit B Topic Report 6-Geological Resources." Below are their comments, edited only to increase clarity and decrease redundancy. They are arranged here in section order of the Geological Resources document. When multiple reviewers comment on the same section, their comments are labeled as Reviewer 1, Reviewer 2, etc. These labels only apply to that particular section; Reviewer 1 in one section is usually not the same as Reviewer 1 in another section.

Reviewers are not individually identified.

\subsection{Geological Resources: Reviewer 1}

1. First paragraph, fourth line: Change

"...will pick up a single mooring (SPM) buoy."

to

"...will pick up one of two single mooring (SPM) buoys".

\subsection{Geological Resources: Reviewer 2}

I reviewed and found the section acceptable.

\subsection{Geologic Setting: General comments}

1. The geologic hazard information summarized in this report is not up-to-date. In particular, Woodside needs to adopt UCERF fault characteristics in its evaluation of fault hazards or explain why its characterizations differ from this comprehensive consensus report.

2. The report presents many assertions without citation or supporting evidence.

3. The report does not evaluate the potential for coastal dune erosion or slumping where the pipelines come ashore.

4. The elevated late Quaternary shore platforms notched into Palos Verdes Peninsula and the Ventura coastline along with the intervening coastal plain indicate local differential vertical uplift. In particular, rapid uplift of the Ventura coastline (Holocene uplift rate of 8-10 mm/y) suggests a potential for episodic earthquakeinduced uplift events that might trigger slope failures or local tsunamis. The potential impact on the LNG facility of such episodic uplift events in the coastal zone needs to be considered.

5. The report implies a historic seismicity catalog dating back 4,000 years, when written records for California date back less than 300 years.

6. The report attempts to characterize liquefaction hazard offshore by evaluating sediment layering and grain size in cores that only sample the upper 8 meters beneath the sea floor. The report needs to consider the potential for deeper sand layers to liquefy and compact during seismic shaking, thereby disrupting the DWP equipment or pipelines.

7. The report does not evaluate the impact of storm waves on the proposed pipelines where they cross the inner shelf (10-30 m water depth) seaward of the portion intended to be buried using horizontal directional drilling. 
8. The report does not evaluate the potential for sand waves migrating across the shelf or how intermittent burial and exhumation by such migration might impact the integrity of the pipelines.

9. The report does not evaluate the potential for abrupt release of gas along the fault zones crossed by the pipelines - or its potential impact on the pipelines - during a slip event or triggered by ground shaking from a nearby earthquake.

10. The report does not evaluate whether cold seep communities reside where the proposed pipelines cross the fault zones or whether routing the pipelines around such communities - if necessary - is feasible. The report does not assess the potential for submerged archeological sites along the proposed pipeline route.

11. The report does not present information regarding local dump sites, dredging operations, trawling or deep-line (fisheries) activities that might impact pipeline integrity or damage fisheries equipment.

12. The report anticipates that the pipelines would settle into the softer stretches of the sea bed and "bury themselves", but does not evaluate the potential for differential settlement where they cross sea floor of variable hardness or whether the resultant differential stresses might affect the integrity of the pipelines.

13. Similarly, the report does not evaluate the potential for differential ground subsidence along the onshore portion of the pipelines - related to petroleum withdrawal from the active fields they cross or skirt (Playa del Rey, Hyperion, and El Segundo fields) — and whether the resultant differential stresses might affect the integrity of the pipelines.

14. The fact that ground shaking associated with the July 29, 2008, M5.4 Chino Hills earthquake incurred minor damage at the Los Angeles International Airport (LAX; terminus of the proposed LNG facility) — at an epicentral distance of $\sim 65 \mathrm{~km}$ suggests soil amplification issues not directly addressed in this report. (Knocked out ground radar system; burst water pipe; see for example, http://edition.cnn.com/2008/US/07/29/earthquake.ca/index.html?iref=hpmostpop).

References for studies that are missing from section 6.1

2007 Working Group on California Earthquake Probabilities, 2008, The uniform California earthquake rupture forecast, version 2 (UCERF 2): U.S. Geological Survey Open-File Report 2007-1437 and California Geological Survey Special Report 203 [http://pubs.usgs.gov/of/2007/1437/]. version 1.1

Lajoie, K.R., 1986, Coastal tectonics, in Active Tectonics, Washington, D.C., National Academic Press, p. 95-124. [and references within this publication]

Sarna-Wojcicki, A.M., Lajoie, K.R., and Yerkes, R.F., 1986, Recurrent Holocene displacement on the Javon Canyon fault-A comparison of fault movement history with calculated average recurrence intervals: U.S. Geological Survey Professional Paper 1339.

Wills, C.J., Weldon, R.J., II, and Bryant, W.A., 2008, Appendix A-California fault parameters for the national seismic hazard maps and Working Group on California 
Earthquake Probabilities 2007: U.S. Geological Survey Open-File Report 20071437A, CGS Special Report 203A, SCEC Contribution \#1138A, version 1.0, 37 p.

\subsubsection{Tectonic Setting-Specific comments: Reviewer 1}

1. The description of southern California's tectonic setting presented in this introductory subsection is disjointed and overly vague. The subsection lacks adequate location maps and contains several inaccurate assertions. For example: (a) paragraph 3/sentence 2. A fragment of the Monterey microplate was captured by the Pacific Plate $\sim 19 \mathrm{Ma}$, not the whole Farallon slab 27 Ma as asserted. There is no evidence that the Monterey fragment "un-subducted", rather its change in motion has been identified as a possible mechanism for pulling apart the overlying continental margin; (b) paragraph $4 /$ sentence 2 . Rotation of the western Transverse Ranges was not caused by its capture by the Pacific Plate - rather rotation initiated when two early strands of the San Andreas transform boundary were "misaligned" forming a large "left step-over"; (c) the San Andreas transform boundary was not a "predominately extensional regime" prior to a 5-Ma change in relative plate motion. It's always been a transform boundary, with varying components of compression or extension depending on time and location.

2. The tectonic information cited in this subsection is not up-to-date. In particular, the report needs to incorporate recent tectonic reconstructions by Dickinson and others (1996, 1997) and Wilson and others (2005) into its description of the tectonic setting, as well as constraints on Holocene to late Pleistocene vertical tectonism by Lajoie (1986) and Sarna-Wojcicki and others (1986).

3. This subsection lacks adequate discussion of the evolution of fault-block motion across southern California, expectation of large earthquakes associated with block motion, reasons for rapid rates of subsidence in trans-tensional basins (Los Angeles basin in particular), reasons for rapid rates of uplift along south side of western Transverse Ranges (Ventura coast), reasons for volcanic units with Neogene basin strata, nature of the tectonic boundary between the western Transverse Ranges and inner Continental Borderland in the vicinity of proposed LNG facility.

References for studies that are missing from 6.1.1

Dickinson, W.R., 1996, Kinematics of transrotational tectonism in the California Transverse Ranges and its contribution to cumulative slip along the San Andreas transform fault system: Boulder, Colo., Geological Society of America Special Paper $305,46 \mathrm{p}$.

Dickinson, W.R., 1997, Tectonic implications of Cenozoic volcanism in coastal California: Geological Society of America Bulletin 109, p. 936-954.

Lajoie, K.R., 1986, Coastal tectonics, in Active Tectonics, Washington, D.C., National Academic Press, p. 95-124. [and references within this publication]

Sarna-Wojcicki, A.M., Lajoie, K.R., and Yerkes, R.F., 1986, Recurrent Holocene displacement on the Javon Canyon fault-A comparison of fault movement history 
with calculated average recurrence intervals: U.S. Geological Survey Professional Paper 1339.

Wilson, D.S., McCrory, P.A., and Stanley, R.G., 2005, Implications of volcanism in coastal California for the deformation history of western North America: Tectonics, v. 24 , no. 3,22 p.

\subsubsection{Tectonic Setting: Reviewer 2}

Page 6-4, paragraph 2. They probably mean "the Newport-Inglewood-Rose Canyon Fault, the Palos Verdes-Coronado Bank fault" as this is the commonly accepted terminology.

\subsubsection{Tectonic setting: Reviewer 3}

Additional references could be included for academic completeness.

\subsubsection{Tectonic Setting: Reviewer 4}

Page 6-3, paragraph 2: For the past 8 million years, plate motions have been relatively constant (Atwater and Stock, 1988).

Page 6-3, paragraph 3-Minor inconsistency - states that margin goes from extension to predominately transform, and then talks about reverse separation faults. Also they state that "Baja California began to impinge on Southern California, yet in the previous paragraph they state that Baja is attached to the Pacific Plate.

Page 6-3. paragraph 4-They need to give reference for how they came up with 10 $\mathrm{mm} / \mathrm{yr}$ in the offshore (this value may be high).

Page 6-3 paragraph 2-The prevailing notion is that the Newport-Inglewood is linked to the Rose Canyon (not Palos Verdes and Rose Canyon). Also, the Coronado Bank Fault (which has been linked to the Palos Verdes) and the San Diego Trough fault (which may be linked to the San Pedro Basin fault and thus of interest to this study) are not mentioned.

Page 6-3. paragraph 3-I disagree that Santa Catalina Island represents a major restraining bend along the San Diego Trough Fault Zone (terraces suggest that Santa Catalina Island is probably going down).

Page 6-4 paragraph 4-This paragraph is redundant to that above, although THUMS fault is added. Also, they omit a complexity in the San Clemente Fault story - a number of earthquakes display left lateral focal mechanisms on northwest-trending fault planes, which are opposite to that expected for San Andreas system tectonics. This includes the largest in the region, the M5.9 "Christmas Day" earthquake on San Clemente Island in 1951 (G. Roquemore, 1997; Legg, 1980).

\section{References}


Atwater, T.A., and Stock, J., 1988, Pacific-North American plate tectonics of the Neogene southwestern United States-An update: International Geological Review, v. 40, p. 375-402.

Legg, M.R., 1980, Seismicity and tectonics of the inner continental borderland of southern California and northern Baja California, San Diego, Calif., Scripps Institution of Oceanography, Master's Thesis, $60 \mathrm{p}$.

Roquemore, Glenn, ed., 1997, The seismic risk in the San Diego region-Special focus on the Rose Canyon fault systems: workshop proceedings, Darby, Penn., Diane Publishing Company, p. 59.

\subsubsection{Regional physiography and geomorphology: Reviewer 1}

"The eastern margin of the basin is characterized by a broad continental slope, which is dissected by the inactive Santa Monica submarine canyon and the active Redondo submarine canyon."

I think this statement is based on work by Don Gorsline published during the 1985-1995 period. Modern seismic-reflection and multibeam-bathymetry data have much higher resolution than data that were available 20 years ago. In particular, in Fugro's report, the small amount of new multibeam data, collected over the head of the Santa Monica Canyon near the shelf break, shows high relief that differs considerably from the smoothed appearance of the rest of the canyon (for example, fig. 6-8). This difference could be an artifact of data resolution, that is, the sharper relief may point to recent activity that is obscured by older, perhaps lower-resolution data. The point is that there might be some unacknowledged hazard from the runout of turbidity currents or hyperpycnal flows. It's interesting that the two canyons nearest the project site - Santa Monica and Redondo - supposedly provide only a low volume of turbidity currents to the Santa Monica basin (for example, fig. 6-21). I suggest they study these two canyons more completely, using modern multibeam and seismic.

\subsubsection{Regional Physiography and Geomorphology: Reviewer 2}

Page 6-5, paragraph 5: (minor) Should cite sources for Redondo Canyon fault (eg. Nardin and Henyey. 1978) and control on the canyon. Actual control of canyon is somewhat circumspect, as fault appears to be located south of the canyon instead of in the axis where originally mapped.

Page 6-5, paragraph 6: (minor): Redondo Knoll needs to be identified on figs 6-4, 6-7.

Page 6-5, paragraph 7 (minor - mod): Discussion of LA Basin should include distinction between western basin (bounded on east by Newport-Inglewood fault and west by the PV fault) and the central LA Basin (east of N-I fault. The shoreline defines the onshore portion of the western LA basin, still within the Borderland province. 


\subsubsection{Regional Physiography and Geomorphology: Reviewer 3}

Page 6-5, paragraph 4 - Northwest of the Palos Verdes peninsula, the Palos Verdes fault does not offset the sea floor and is covered by undeformed sediments (Fisher and others, 2003).

\section{Reference}

Fisher, M.A., Normark, W.R., Bohannon, R.G., Sliter, R.W., and Calvert, A.J., 2003, Geology of the continental margin beneath Santa Monica Bay, southern California, from seismic-reflection data: Bulletin of the Seismological Society of America, v. 93, p. 19551983.

\subsubsection{Regional Geology and Stratigraphy: Reviewer 1}

Page 6-6, paragraph 2. The text implies that these "five en echelon anticinoria" are all genetically related. At least some of them, however, probably formed at different times and for different reasons.

\subsubsection{Regional Geology and Stratigraphy: Reviewer 2}

Page 6-6, paragraph 2 (minor): Should add that above lower Pliocene (mid-Repetto age) rocks on the Palos Verdes Hills is a veneer of middle Pleistocene marine sediment along the NE margin.

\subsubsection{Stratigraphy of proposed site and 6.4.2.4 Stratigraphy of AES site: Reviewer 1}

The report is comprehensive in its scope, identifies and properly addresses the natural hazards at local and at regional scales with respect to the proposed LNG deep-water port and pipeline. Gaps in the present sets of data are identified and the need for more thorough investigations, such as in the non-barred high-energy near-shore where the pipelines will be constructed across the shoreline using HDD technology. In this reach, immediately offshore of the beach, there are no detailed seismic data nor are there much if any geotechnical data. Further studies will be called for to be used for developing detailed designs, and the consultants acknowledge this. However, the existing data are sufficient to select an appropriate route for the pipeline. The LAX preferred alternative is superior, for the reasons that the consultants ably articulate.

There are minor issues that could be raised concerning fine points of the stratigraphy. The consultants use some older work such as that of Poland and others, which, while basically sound, predates much of the more recent work by Ponti and others on the stratigraphy of the San Pedro Formation. The newer works deal more with revisions to the age relations within the San Pedro Formation, but more directly at issue for the present project are the material properties of the sediments with respect to the project's engineering. The older work is sufficient to that end, so I make no issue of this here.

\subsubsection{Stratigraphy: Reviewer 2}

Page 6-6, paragraph 4 (mod): In reference to the geologic map (fig. 6-10)—what is the source? There are more recent compilations and assessment of fault activity (Saucedo, 2003; Fisher et al, 2004) that should probably be used, or at least differences noted. 
Page 6-6, last paragraph (mod): Report should state average thickness of the turbidity sequences described from Ocean Drilling Program (ODP) Site 1015 as this would have relevance to design of the surface pipeline in that area.

General comment: Overall the discussion of the Santa Monica Basin stratigraphy is a little confusing as written and doesn't reconcile well the observations from the ODP site to the regional geology.

Section 6.1.3.2 HDD Shore Crossing Soils and Stratigraphy (and relevant parts of appendix N): Reviewer 1

No specific comments on text. Exploration method and descriptions appear reasonable and adequate. It is clear that the current investigation has yielded little information on the nature of the stratigraphy in the offshore area below about 4-8 ft below ground surface, especially because of the difficulty in interpreting seismic data in water depths below about 30 feet, which is the case for the bulk of the HDD area. Also, the stratigraphic framework from which they base their nomenclature and correlations is quite old and recent studies (for example, Ponti and others, 2007) have shown that there are considerable correlation problems using the older nomenclature. Nomenclatural issues don't have a lot of relevance to this design, but it appears from the preliminary design of the HDD that the preferred design is to run the bulk of the HDD through the Pico Formation, where there is a much lower likelihood of encountering abrupt and frequent physical properties changes during drilling. Toward that end, there is virtually no information on the location, trend, and engineering properties of the Pico Formation in the offshore area. I support Fugro's recommendation that additional subsurface explorations be performed in the offshore using rotary drilling techniques and piston cores which would support engineering design of the pipeline alignment in the offshore region.

\subsubsection{HDD Shore Crossing Soils and Stratigraphy: Reviewer 2}

I reviewed and found the section acceptable.

\subsubsection{Active faults: Reviewer 1}

An article that appeared after the Fugro report was completed (Geiser and Seeber, 2008) purports to show an integrated view of the thrust fault system under the Santa Monica Mountains and should be included in the discussion of the potential hazards from these faults.

\section{Reference}

Geiser, P.A., and Seeber, L., 2008, Three-dimensional seismo-tectonic imaging-An example from the southern California Transverse Ranges: Journal of Structural Geology, v. 30, p. 929-945. 


\subsubsection{Active Faults: Reviewer 2}

Page 6-9, paragraph 1 . They need to better explain their seismotectonic model and how they came up with the $1 \mathrm{~mm} / \mathrm{yr}$ (which may be reasonable, but the value is basically unknown).

Page 6-11, paragraph 7 - This earthquake was $\mathrm{M}_{\mathrm{L}}$ 5.3, not $\mathrm{M}_{\mathrm{W}}$ 6.0.

\subsubsection{2 and 6.1.4.3: Historical Seismicity and Seismicity Catalog}

1. The 1933 earthquake is included in table 1 but also mentioned in the text as a significant earthquake outside of the study area. Meanwhile the text conspicuously fails to mention the $\mathrm{M}_{\mathrm{w}} 6.7$ Sylmar quake of 1971 .

2. More significantly, earthquakes prior to 1925 are completely ignored in both the text and in Table 2. The easiest way to fix table 2 would be to change the title to "Damaging $20^{\text {th }}$ century earthquakes offshore southern California." But at a minimum these events should be mentioned in the text:

"The earliest known earthquake in proximity to the study area was a 22 November 1800 event that caused damage in San Diego. The Rose Canyon fault zone offshore from Encinitas is reported in CDMG (2000) as the probable source of this earthquake, the magnitude of which is estimated roughly as 6.5. A pair of large earthquakes struck southern California in December of 1812; the second of these, on 21 December, is thought to have been approximately M7, and to have occurred in the Santa Barbara channel, although the location remains uncertain. Three other earthquakes caused at least light damage in San Diego in the $19^{\text {th }}$ century: an 1862 earthquake near San Diego $(\mathrm{M} \sim 6)$, the 1892 Laguna Salada earthquake in northern Baja California $(\mathrm{M} \sim 7)$, and an 1894 earthquake (M 5.75) east of San Diego. It is not possible to identify the faults that produced the 1862 or 1894 events."

3. (Minor point.) I would rewrite, "Offshore, there are four areas..." as, "Significant instrumental and historical seismicity has been concentrated in four areas:"

6.1.4.4-6.1.4.7 Design Criteria for LNG Facilities, NFPA Maximum Credible Earthquake (MCE), NFPA Operating Basis Earthquake (OBE) and NFPA Safe Shutdown Earthquake (SSE)

Because, according to the proposal, the design code that will be adopted for LNG import facilities permitted in accordance with the Deepwater Port Act is unknown, "for perspective" the authors have merely described the 2001 and 2006 National Fire Protection Agency (NFPA) requirements in Sections 6.1.4.5-6.1.4.7. According to the authors, the design of onshore LNG facilities within the United States is conducted in accordance with the 2001 version of the NFPA 59A code. In 2006, the NFPA published an update of this code, as mentioned in the proposal. The most recent 2009 edition of the NFPA 59A code is not mentioned in the proposal.

Although the proposal presents (in table 6.3) the exceedance probabilities for different return periods (that is, inverses of the annual frequencies of exceedance tolerated for 
earthquake ground motions used for design), it does not provide the ground motion response spectra at the DWP for the return periods and respective exceptions associated with the NFPA Maximum Credible Earthquake (MCE), Operating Basis Earthquake (OBE), and Safe Shutdown Earthquake (SSE) ground motions. Perhaps this is because, as stated in the proposal, "the actual design return periods for the DWP Project may vary from those required by NFPA." Thus, it is of primary importance that the applicable design code and/or design return periods for the DWP Project be determined.

Recent changes to the design return periods for building structures (for the upcoming 2009 editions of the NEHRP Recommended Provisions for Seismic Regulations for New Buildings and Other Structures) and nuclear power plants (as reflected in the 2007 U.S. Nuclear Regulatory Guide 1.208, "A Performance-Based Approach to Define the SiteSpecific Earthquake Ground Motion”) should be considered for LNG facilities, including those to be permitted in accordance with the Deepwater Port Act. The former changes (for buildings) have been led by the USGS (for example, please see the Luco and others, 2007, reference below), and in 2004-2006 the USGS reviewed the application of the latter to a nuclear power plant near Clinton, Illinois.

\section{Reference}

Luco, N., Ellingwood, B.R., Hamburger, R.O., Hooper, J.D., Kimball, J.K., and Kircher, C.A., 2007, Risk-targeted versus current seismic design maps for the conterminous United States: Proceedings of the 2007 Structural Engineers Association of California (SEAOC) Convention, p. 163-175.

\subsubsection{Sediment Transport and Depositional Environments}

Other reviewer's concerns regarding possible hyperpycnal flows out of Mugu Canyon in response to large floods in the headwaters of Calleguas Creek are reasonable. I am unaware, however, of specific studies that evaluate the erosive power or distal impact of such flows. Such flows might impact slope stability in the vicinity of Mugu Canyon but the influence of subsequent (or potential) slope failures in the distal reaches of Santa Monica Basin (in the area of the pipeline) are uncertain.

As Hogan and McNeilan note, the sediment in the central Santa Monica Basin is "soft", but I did not see them address erosive susceptibility to turbidity currents and/or debris flows, nor do they comment on how deep in the sediment column they expect the pipe to settle. Perhaps these issues are covered elsewhere in other (engineering?) parts of the report.

\subsubsection{Sediment Transport: Reviewer 1}

Calleguas Creek is also a major source of sediment to the area. Because it empties near the head of Mugu Canyon it has the potential for generating hyperpycnal flows directly into the canyon. I know of few if any other situations like this in southern California. Such hyperpycnal flows (from large floods discharging large quantities of sediment to the ocean) could occur during or shortly after a large storm. They could be a hazard to the pipes out in Santa Monica Basin directly or they could induce slope failures in the canyon 
(through erosion and undercutting of slopes) leading to much larger turbidity currents that would have an even more significant effect.

The accumulation rates mentioned in the last paragraph are long term (past 32,000 years). For the much shorter term (last 100 years) cite Alexander and Venherm (2003).

Many of the references cited are fairly old. Also quite a few statements are made without citing a reference cited to support the statement. Here are a few newer references that may bear on sediment transport and depositional environments in Santa Monica Bay.

Alexander, C., and Venherm, C., 2003, Modern sedimentary processes in the Santa Monica, California continental margin-Sediment accumulation, mixing and budget, Marine Environmental Research, v. 56, p. 177-204.

Edwards, B.D., Dartnell, P., and Chezar, H., 2003, Characterizing benthic substrates of Santa Monica Bay with sea-floor photography and multibeam sonar imagery: Marine Environmental Research, v. 56, p. 47-66.

Edwards, B.D., Field, M.E., and Kenyon, N.H., 1996, Morphology of small submarine fans, inner California continental borderland, in Gardner, J.V., Field, M.E., and Twichell, D.C., eds.: Geology of the United States seafloor-The view from GLORIA, p. 235-249.

Noble, M., and Xu, J.P., 2003, Observations of large-amplitude cross-shore internal bores near the shelf break, Santa Monica Bay, CA: Marine Environmental Research, v. 56, p. $127-150$.

Romans, Brian, 2008, Controls on distribution, timing, and evolution of turbidite systems in tectonically active settings-Upper Cretaceous Tres Pasos Formation, southern Chile, and Holocene Santa Monica Basin, offshore California: Palo Alto, Calif., Stanford University, Ph.D. dissertation.

Sommerfield, C.K., and Lee, H.J., 2004, Across-shelf sediment transport since the last glacial maximum, southern California margin: Geology, v. 32, p. 345-348.

Warrick J.A., Xu, J.P., Noble, M.A., and Lee, H.J., 2008, Rapid formation of hyperpycnal sediment gravity currents offshore of a semi-arid California river, Continental Shelf Research, v. 28, p. 991-1009.

\subsubsection{Sediment Transport: Reviewer 2}

1. The 4th paragraph: "Storm-generated sediment flows" is a very ambiguous term. I suppose the authors meant hyperpycnal flows or turbidity current, not debris flows.

2. Cliff erosion is another major land-based sediment source in southern California.

3. The sediment transport path of "river-beach-canyon-basin" is qualitatively well known. It is however necessary to point out that it is poorly understood quantitatively. For 
instance, hyperpycnal flows and/or small scale turbidity currents may occur at subannual intervals, but large scale turbidity currents that can transport large volume of sediment into the basin may happen every few hundreds years, but how much? how often?

4. Dume submarine canyon is probably more an active conduit as a sediment source than Santa Monica Canyon, therefore should have been discussed.

\subsubsection{Depositional Environments: Reviewer 1}

In the second paragraph they refer to the bottom as soft (a measure of strength) but then cite the ability of an acoustic beam to be absorbed (a measure of geoacoustic properties). These are not the same thing; acoustics measure reflectivity or absorption, not strength.

Third paragraph. Historically Hueneme Canyon has been more active than Mugu Canyon. However, sand is presently being bypassed by a pipe around the head of Hueneme Canyon and much of this may find its way into the head of Mugu Canyon. This could change the stability of Mugu Canyon and could lead to an anthropogenically influenced failure down Mugu Canyon at some time in the future. This failure could be of a different nature from those observed in the ODP boring. That is, it might have a higher likelihood than those given in paragraph 6 of this section. They should at least do an evaluation of what's known. They need to carefully look at the how much sediment is coming in and evaluate the risk of sediment flow induced failure of the pipeline, especially considering the anthropogenic changes. Because of the anthropogenic changes, they can't just rely on the geologic record.

They should consider the possibility of a debris flow moving out onto the floor of Santa Monica Basin. In other fan systems we sometimes see both turbidites and debris flow deposits. Loading on a pipeline from a debris flow might be greater than loading from a turbidity current. They need to evaluate whether there's a risk from debris flows as well as turbidity currents coming down the canyons and channels and out onto the pipeline area.

First paragraph in Nearshore and Onshore Zone: coarse sediment near the shelf break (as shown in photographs in Edwards and others, 2003), may occur because of the internal bores discussed by Noble and Xu, 2003 (or other internal wave action).

\subsubsection{Depositional Environment: Reviewer 2}

1. Turbidity currents or turbidity flows, but not turbidity current flows.

2. The 2nd half of the 2nd paragraph under Lower Slope Apron (p. 6-19) is confusing and doesn't quite make sense. "The turbidites on the lower slope are thought to represent...." Highly dense or low dense? Contradicting! Also, just because the turbid cloud is 60-100 $\mathrm{m}$ thick doesn't mean it will affect all the lower slope apron of the whole basin.

\subsubsection{Geotechnical Conditions: Reviewer 1}

The geotechnical sampling and in situ testing program is very extensive and impressive. 


\subsubsection{Geotechnical Conditions: Reviewer 2}

This is a well-written discussion on the geotechnical characteristics of the sea floor in the vicinity of the proposed pipeline route. The consulting company performed a detailed geotechnical investigation that involved piston cores vibracores and a sea-floor CPT investigation. These allow a consultant to make very focused observations on the geotechnical character of the route.

\section{$\underline{\text { 6.1.6.3 Santa Monica Basin }}$}

The authors provide detailed information on the number of turbidites in the upper $8 \mathrm{~m}$ of the sediment column and some information on the times of occurrence of the turbidity current events. Perhaps it is handled somewhere else in the report, but it would be interesting to know how this type of information would be used in an engineering design. That is, the grain size, areal extent, and thickness of turbidite probably provide information on the flow conditions that were present when the turbidity current was flowing. Also, the dating of the deposits could be used in a statistical analysis of the rate or recurrence versus size. I would think this sort of information would be required to design pipelines to withstand future turbidity current events or to predict the likelihood of failure events (along with considering the implications of failure). Again as I mentioned above, is there any indication of debris flows reaching the floor of the basin or do they only exist farther up the fan? They should use this information on the temporal occurrence of turbidity currents to determine the probability of a destructive turbidity current striking the facility during its lifetime. They should also use characteristics of the deposit to determine the character of a design turbidity current and resulting load that would be applied to the structure. They should show how to use the information in their design.

\subsubsection{Continental Slope}

The authors show that the planned pipeline route has been placed to minimize the slope steepness and avoid older outcrops. Are there design criteria that show that any particular degree of bottom hardness or slope steepness is too much or is it possible to design the system for any conditions of hardness and steepness? Authors should specify what slope steepness would be too great.

\subsubsection{Geologic Hazards}

In general, I would conclude that this is a very thorough report and that it has been done by very competent professionals. I see no obvious deficiencies or cause for concern in that the engineering plans seem to be reasonable and take into account the geologic hazards in an appropriate manner.

\subsubsection{Surface Fault Rupture Hazard}

No comments. Structure in this area is complicated, and the report does a reasonable job of trying to make sense of the conflicting views of the geologic structure. 
6.1.7.1 Surface Fault Rupture Hazard—Surface Fault Displacement Estimates and 6.1.7.2 Strong Ground Motion and Appendix M: Reviewer 1

My overall impression of the earthquake hazard assessment done in support of the proposal to build a LNG facility at one of two potential locations on the southern California coast is that a reasonable and thorough analysis was conducted. All known fault zones are identified and discussed in detail.

My main comment is that significant updates to the earthquake hazard assessment in California have come on line during 2007-2008, including a new version of the USGS National Seismic Hazard Mapping Project (NSHMP, 2008) maps and a new earthquake probability forecast from the Working Group on California Earthquake Probabilities (WGCEP, 2008). The NSHMP mapping uses the Next Generation Attenuation (NGA) models which have the following updates: (1) the use of VS30 for the site condition, inclusion of a depth of rupture factor, (2) inclusion of hanging wall factors, and (3) inclusion of depth of soil factors. All of the models include non-linear site response effects. Three of the models include the effects of the soil non-linearity on the standard deviation. These changes have some significant effects on hazard assessment including: (1) there is often increased motion, even for 1s spectral acceleration, over the hanging wall of reverse and normal faults, and (2) intermediate to long period median ground motion estimates are reduced compared to previous models (about $25 \%$ near some of the major faults such as the San Andreas). The attached figure 2 highlights some of these effects expressed as a ratio between the 2008 and 2002 NSHMP estimates. 


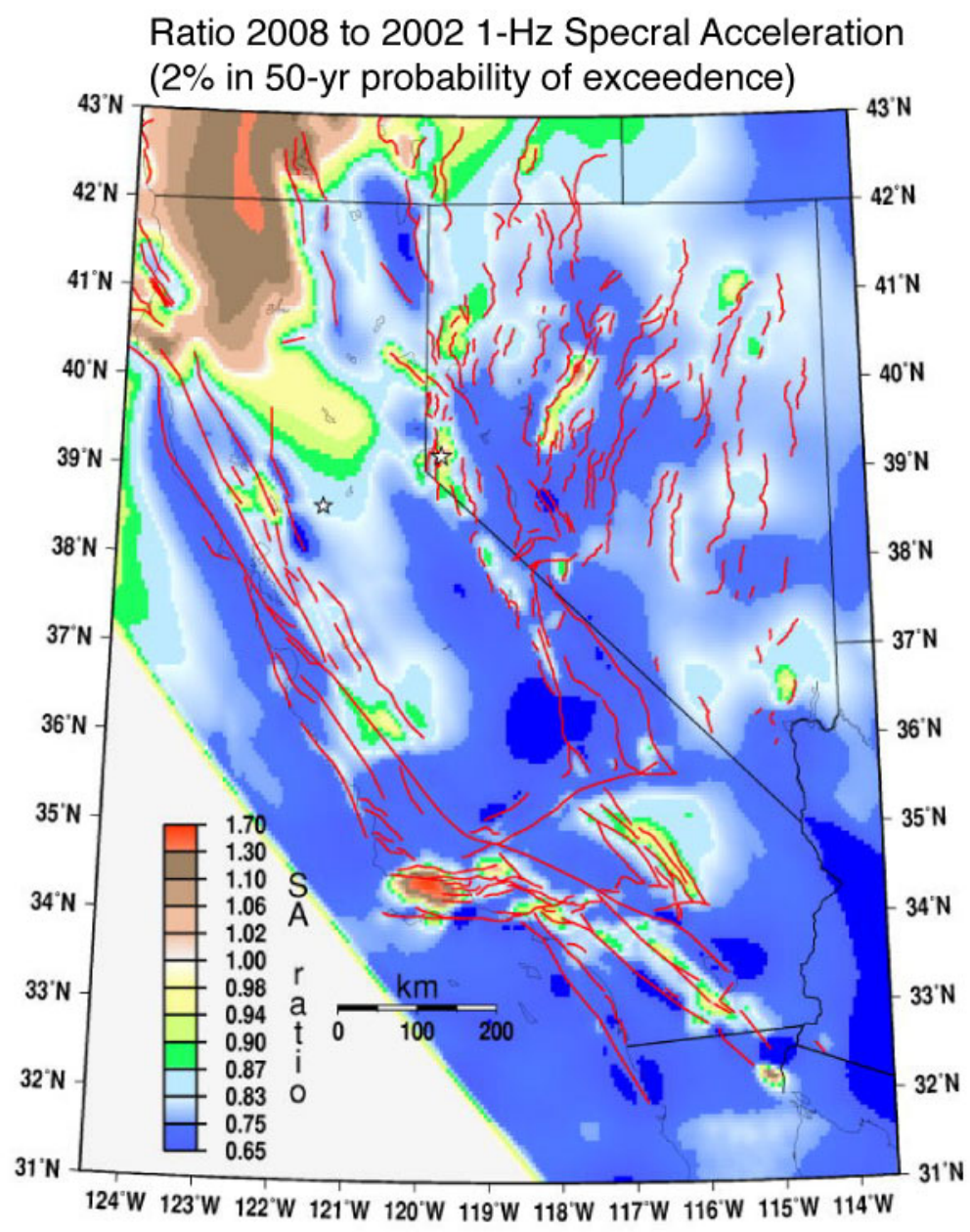

Figure 2. Ratio of 1-Hz spectral acceleration (SA) from National Seismic Hazard Mapping Project (NSHMP) 2008 to NSHMP 2002 maps. Brown to red colors show increased hazard estimates in the 2008 maps, whereas yellow to blue colors show decreased hazard estimates. Offshore regions show significant increases in the 2008 estimate because of the fault hanging-wall effects included in the Next Generation of Attenuation (NGA) relations.

A recommendation is that the hazard assessment provided by Fugro West, Inc., be compared for consistency with the NSHMP 2008 results. Ideally a difference grid for the regions of interest similar to that of figure 2 would be produced. Further, since the Whittier-Elsinore, and San Andreas Faults are discussed, the WGCEP (2007) updated time dependent probabilities for those faults should be considered. 


\section{References}

2007 Working Group on California Earthquake Probabilities, 2008, The uniform California earthquake rupture forecast, version 2 (UCERF 2): U.S. Geological Survey Open-File Report 2007-1437 [http://pubs.usgs.gov/of/2007/1437/].

Frankel, A.D., Petersen, M.D., Mueller, C.S., Haller, K.M., Wheeler, R.L., Leyendecker, E.V., Wesson, R.L., Harmsen, S.C., Cramer, C.H., Perkins, D.M., and Rukstales, K.S., 2002, Documentation for the 2002 Update of the national seismic hazard maps, U.S. Geological Survey Open-File Report 02-420, 33 p. [http://pubs.usgs.gov/of/2002/ofr-02-420/].

Petersen, M.D., Frankel, A.D., Harmsen, S.C., Mueller, C.S., Haller, K.M., Wheeler, R.L., Wesson, R.L., Zeng, Y., Boyd, O.S., Perkins, D.M., Luco, N., Field, E.H., Wills, C.J., and Rukstales, K.S., 2008, Documentation for the 2008 update of the United States national seismic hazard maps: U.S. Geological Survey Open-File Report 2008-1128, 61 p. [http://pubs.usgs.gov/of/2008/1128/].

6.1.7.1 Surface Fault Rupture Hazard - Surface Fault Displacement Estimates and 6.1.7.2 Strong Ground Motion and Appendix M: Reviewer 2

Review of source models used in Probabilistic Seismic Hazard Analysis.

In developing source models for the probabilistic seismic hazard analysis (PSHA), Fugro used previously developed fault models in developing their model in this study. Fugro used:

- Southern California Earthquake Center (SCEC) Community Fault Model Version 2.5 (Shaw and others, 2004): this reference provides detailed geometry of faults, but not slip rates, so must be combined with other data for use in PSHA;

- Revised 2002 California Probabilistic Seismic Hazard Assessment (Cao and others, 2003): this model incorporates the 1996 USGS-CGS seismic hazard model and revisions for the 2002 model;

- CGS Fault Model for FRISKSP and EQFAULT (Blake, 2004): this is largely an attempt to reproduce the input and results of the 2002 USGS-CGS seismic hazard model; and

- Probabilistic Seismic Hazard Analysis for Southern California Coastal Facilities (Savy and Foxall, 2003)

These models and input values were considered in the development of the 2008 USGSCGS seismic hazard model. Because Fugro did not have the benefit of the revisions that were being done at CGS and USGS at the same time they were preparing their model, the results are not the same. In general, Fugro has included more faults, and included slip rates for more faults than were included in the 2008 USGS-CGS seismic hazard model. In several cases, Fugro has included slip rate values for faults in the SCEC Community Fault Model that were not found to be sufficiently well documented for inclusion in the USGS-CGS 2008 seismic hazard model. The net effect of these additional slip rate values is that the Fugro model has more faults that have higher activity rates near the proposed 
facilities than the USGS-CGS 2008 model. This appears to result in a seismic hazard model that is more conservative (results in higher ground motion values) for most offshore areas than the USGS-CGS 2008 model.

The following faults appear to have significantly different long-term slip rate values than the faults in the 2002 USGS-CGS model (faults are arranged by increasing distance from the Santa Monica Bay site, the same order as in Appendix M prepared by Fugro):

DUME-SANTA MONICA SYSTEM ( $2 \mathrm{~mm} / \mathrm{yr}$ in Fugro model, $1 \mathrm{~mm} / \mathrm{yr}$ in USGS-CGS 2008 model)

REDONDO CANYON FAULT ( $1.5 \mathrm{~mm} / \mathrm{yr}$ in Fugro model, slip rate unknown (insufficiently documented) in USGS-CGS 2008 model)

COMPTON STRUCTURE $(0.2 \mathrm{~mm} / \mathrm{yr}$ in Fugro model, slip rate unknown (insufficiently documented) in USGS-CGS 2008 model)

SAN PEDRO ESCARPMENT $(0.2 \mathrm{~mm} / \mathrm{yr}$ in Fugro model, slip rate unknown (insufficiently documented) in USGS-CGS 2008 model)

THUMS-HUNTINGTON BEACH (1.0 mm/yr in Fugro model, not included in USGSCGS 2008 model)

SANTA MONICA BAY FAULT ( $1 \mathrm{~mm} / \mathrm{yr}$ in Fugro model, slip rate unknown (insufficiently documented) on "shelf projection" fault from Community Fault Model included in USGS-CGS 2008 model)

SANTA CRUZ-CATALINA RIDGE FAULT ( $4.0 \mathrm{~mm} / \mathrm{yr}$ on north segment, $1.0 \mathrm{~mm} / \mathrm{yr}$ on south segment in Fugro model, slip rate unknown (insufficiently documented) in USGS-CGS 2008 model)

SANTA CATALINA (ESCARPMENT) $(1.0 \mathrm{~mm} / \mathrm{yr}$ in Fugro model, slip rate unknown (insufficiently documented) in USGS-CGS 2008 model)

SAN PEDRO BASIN FAULT $(2.0 \mathrm{~mm} / \mathrm{yr}$ on north segment, $1.0 \mathrm{~mm} / \mathrm{yr}$ on south segment in Fugro model, slip rate unknown (insufficiently documented) in USGS-CGS 2008 model)

SAN CLEMENTE FAULT $(1.0 \mathrm{~mm} / \mathrm{yr}$ on north, Pilgrim Banks segment in Fugro model, $3.0 \mathrm{~mm} / \mathrm{yr}$ on segment A, $4.0 \mathrm{~mm} / \mathrm{yr}$ on segments B and C in Fugro model, slip rate unknown (insufficiently documented) in USGS-CGS 2008 model)

SAN DIEGO TROUGH FAULT $(2.0 \mathrm{~mm} / \mathrm{yr}$ in Fugro model, slip rate unknown (insufficiently documented) in USGS-CGS 2008 model)

SANTA CRUZ BASIN FAULTS ( $1.0 \mathrm{~mm} / \mathrm{yr}$ in Fugro model, not included in USGSCGS 2008 model)

CORTEZ BANKS FAULTS $(1.0 \mathrm{~mm} / \mathrm{yr}$ in Fugro model, not included in USGS-CGS 2008 model)

It should be noted that the addition of these estimated slip rates for a number of faults offshore of southern California results in additional right-lateral shear across the region. In developing the 2008 USGS-CGS hazard model, used by the Working Group on 
California Earthquake Probabilities and the National Seismic Hazard Mapping Program, the overall right lateral shear rates from faults was compared with rates from geodetics and from long-term plate motions. There was good correspondence between the total of fault slip rates in that model and both the overall geodetic rate and the long term plate rate. It appears that the model developed by Fugro includes at least $6 \mathrm{~mm} / \mathrm{yr}$ of rightlateral shear not included in the 2008 model. This additional right lateral shear may result in the model by Fugro being inconsistent with the geodetic and plate rates.

In addition to the differences in slip rates in the Fugro model, when compared with the USGS-CGS 2008 model, there are differences in the potential for combinations of faults and fault segments in the models. Many faults in the Fugro model have the potential for earthquakes that rupture multiple segments or segments of adjacent faults. This concept was adopted and applied to a few faults by the WGCEP (2008). There are several cases where the Fugro model includes the potential for multi-segment rupture but the USGSCGS 2008 model does not. There are two major fault zones where the USGS-CGS model allows for multisegment rupture but the Fugro model does not. These are the Newport Inglewood-Rose Canyon Zone, where the USGS-CGS model includes the potential for a rupture of the entire zone in a M7.5 earthquake and the Palos Verdes-Coronado Bank Fault Zone where the USGS-CGS model includes the potential for a rupture of the entire zone in a M7.7 earthquake. I think these differences reflect both Fugro and the WGCEP recognizing the same issue, that multi-segment earthquakes need to be considered in a PSHA, and implementing slightly different solutions to the problem.

6.1.7.1 Surface Fault Rupture Hazard - Surface Fault Displacement Estimates and 6.1.7.2 Strong Ground Motion and appendix M: Reviewer 3

Comments on Probabilistic Seismic Hazard Analysis

1. Uses standard methodology and attenuation relationships (from 2002 maps not 2008 maps).

2. Incorporates near source directivity effects and takes into account fault-parallel and fault-normal ground motions.

3. Applies site condition consistent with $\mathrm{Vs} 30=310 \mathrm{~m} / \mathrm{s}$, does not use borehole data directly

4. Proposed ground motions for Santa Monica DWP site at $118.808 \mathrm{~W}, 33.698 \mathrm{~N}$ appear to be higher than the new 2008 USGS hazard model (ground motions) for all periods checked (see fig. 3). For operating basis earthquake spectral acceleration (OBE Sa) the USGS ground motions are generally 27 to $41 \%$ lower. For safe shutdown earthquake spectral acceleration (SSE Sa) the USGS ground motions are generally 7 to $33 \%$ lower.

5. Ground motions for Santa Monica DWP are lower than ground motions at a site directly over the Palos Verdes Fault at site 118.56 W, 33.97 N (see fig. 3). USGS 
ground motions are typically up to $15 \%$ higher for OBE Sa and 35 to $37 \%$ higher for the SSE Sa ground motions.

6. Deaggregation plots generated by the USGS contain contributions from the San Andreas Fault whereas the deaggregation plots in the report do not show these contributions from distant sources (see fig. 4).

Fault rupture hazard model:

1. The assessment is based on the Youngs and others (2003) probabilistic methodology for fault displacement hazard.

2. In addition, the analysis uses the empirical relationship for maximum fault displacement of Wells and Coppersmith (1994).

3. Parameters applied to the analysis include Palos Verdes north and north and south sections together which result in M 6.6 and 7.3 earthquake ruptures, respectively. Currently the new WGCEP 08 model allows for M 7.7 (+/- 0.2) magnitudes.

4. Parameters applied to the analysis of the San Pedro segments also range from about 6.5 to 7.3. This fault is not included in the new WGCEP 08 model.

5. PFDHA results yield displacements from 0 to $7 \mathrm{~m}$. The Wells and Coppersmith $M$ 7.7 yields a maximum displacement of $7.1 \mathrm{~m}$. If one considers a 7.9 event, the maximum displacement would be about $10 \mathrm{~m}$. The M 7.9 Denali earthquake (strike-slip) in Alaska resulted in many $5 \mathrm{~m}$ displacements and displacements as much as $9 \mathrm{~m}$. The pipeline crossing is near the end of the fault so the displacements would probably be less than the maximum. 


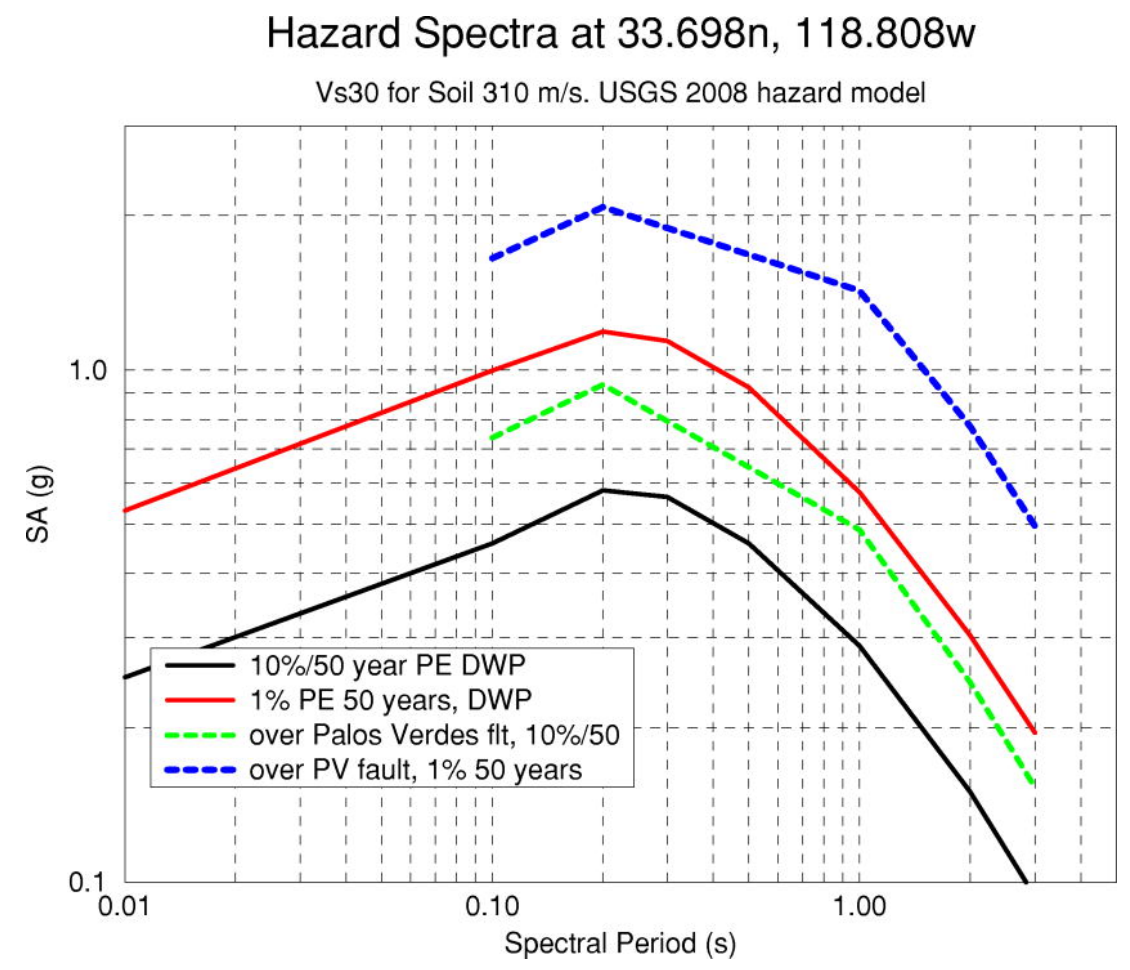

Figure 3. Hazard spectra for the Santa Monica site and for a site over the northern Palos Verdes fault for the OBE (10\% in 50 year) and SSE (1\% in 50 year) ground motions on soil with $\mathrm{Vs} 30=310 \mathrm{~m} / \mathrm{s}$. SA stands for spectral acceleration. 


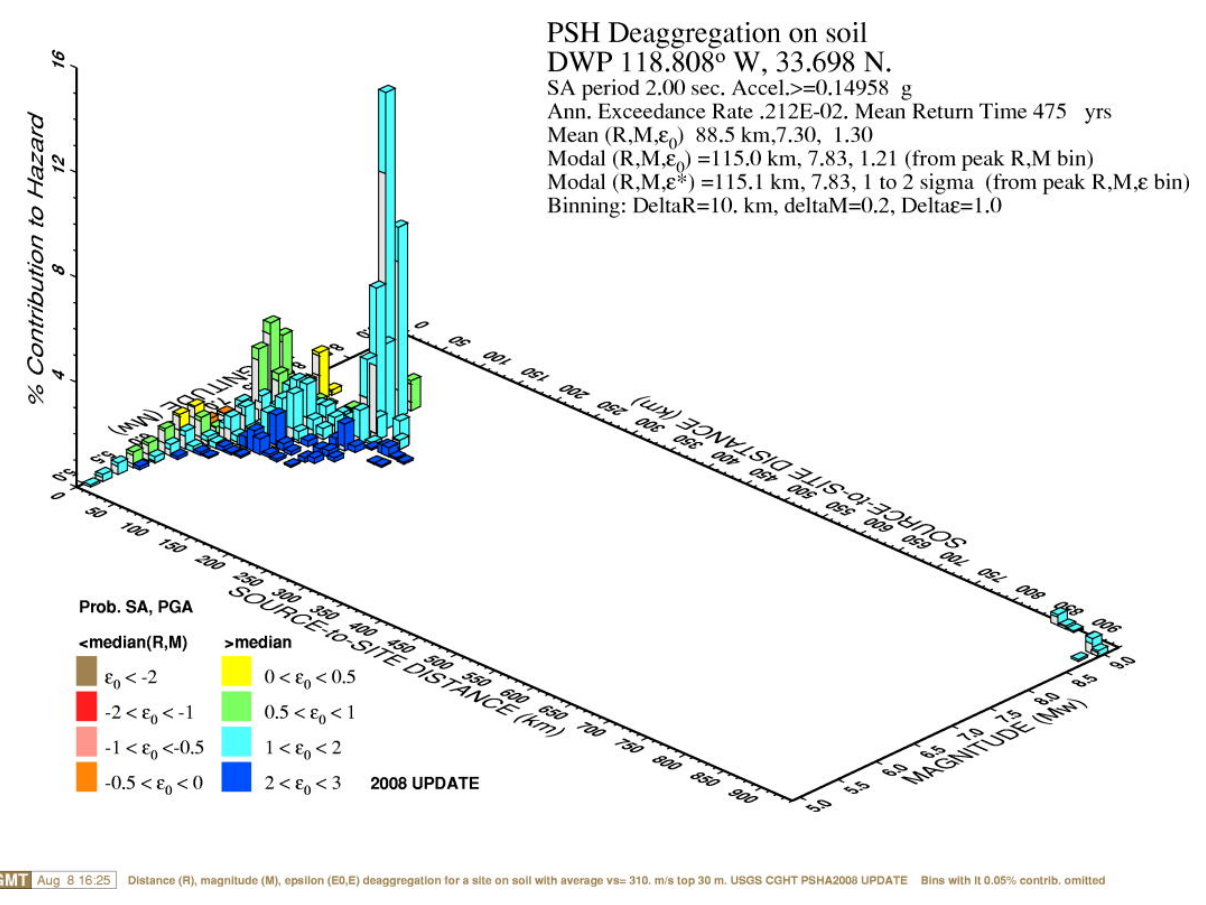

Figure 4. Deaggregation for the Santa Monica site using the USGS (Petersen and others, 2008) model.

\subsubsection{2 and 6.4.2.5 Strong Ground Motions}

These sections give a very brief description of the largest earthquakes that have occurred historically in the adjacent portion of southern California. They mention the possibility of earthquakes on the offshore faults and rightly note that both strike-slip and thrust earthquakes can occur there.

In section 6.17 .2 , there is a sentence that describes the ground motions with a $2 \%$ probability of exceedance in 50 years:

"This level of ground motion represents the basis for the USGS recommended mid-level design criteria for an LNG facility (NFPA, 2001).”

This statement is incorrect. The USGS does not issue recommendations about design criteria. The USGS produces seismic hazard maps that are then used by engineers in the building codes. It was the engineers involved with the NFPA code who chose the design level for LNG facilities.

The probabilistic seismic hazard assessment (PSHA) done for this preliminary study used four ground-motion attenuation relations: Abrahamson and Silva (1997), Boore and others (1997), Campbell and Bozorgnia (2003), and Sadigh and others (1997). This is described in section 4.3.3 in part 4 of the Appendix to the PSHA report. With the recent release of the Next Generation of Attenuation (NGA) relations (published in Earthquake 
Spectra, February 2008), the older attenuation relations have been superseded. The NGA relations should be used in the PSHA. It is critical that this PSHA incorporate the appropriate Vs30 (30 m averaged shear-wave velocity) for the sites of interest, as well as basin-depth terms, when implementing the NGA relations. It is also important that the PSHA includes the proper range of depth to top of rupture, focal mechanism type, and hanging wall terms, as appropriate. The applicant should also be aware that the NGA relations may not capture all of the epistemic uncertainty in ground motions and should consider adding additional epistemic uncertainty. This epistemic uncertainty affects the mean hazard curves. Additional epistemic uncertainty to the NGA relations was included in the 2008 USGS national seismic hazard maps (Petersen and others, 2008).

It would be best if the applicant used site-specific profiles of shear-wave velocity to determine site response. It would also be desirable for the applicant to perform threedimensional simulations of ground motions for certain earthquake scenarios to quantify the effects of basin surface waves at the proposed facilities and along the pipeline route.

\subsubsection{Liquefaction and Lateral Spreading}

The reviewers found the section acceptable.

\subsubsection{Sediment Transport and Mass Movement: Reviewer 1}

First paragraph. From the reference list it looks as if the Hogan (1986) reference only covers Santa Maria Basin which is really not in the borderland. Accordingly it is not a good citation for the "distribution of mass movement processes in the Borderland." Lee has just written a general paper on the subject but it is not yet published. Partial coverage is given by Lee and others (2004).

Turbidity currents - third paragraph. The three references cited do not refer to Hueneme Fan and Santa Monica Basin but rather to general knowledge about turbidity currents. The next paragraph cites references that are more relevant to this specific environment.

Last two paragraphs-As I mentioned under 6.1.6.3, the characteristics of the turbidite deposit may provide information about the turbidity current that produced the deposit. I would think it would be worthwhile to try to deduce the characteristics of the turbidity current in this way. The authors suggest that the pipeline will settle into the soft sea floor and this will protect it to some extent from turbidity currents. This may not be the case because the turbidity current could erode the soft sediment and the pipeline might not settle as much as expected. Turbidity currents are known to cause serious damage to structures on the sea floor (as evidenced by the 1929 Grand Banks event that broke many trans-Atlantic cables). The designers certainly should use all of the information available and the latest in knowledge about turbidity current flow conditions to design the pipelines against rupture. Given the difficulty in anticipating the effects of turbidity currents the consequences of a pipeline rupture should also be evaluated.

Slumps and slides - we agree that the available information indicates that the risk of larger submarine landslides along the proposed route is low. However, we may not know enough about the occurrence of small failures (a few meters across) to be able to make a 
definitive statement about them. They should state how small a landslide they could identify with their acoustic system, and they also need to identify how large a landslide needs to be to be a risk to the facility.

\subsubsection{Sediment Transport and Mass Movement: Reviewer 2}

The last paragraph of Turbidity Currents (page 6-33) - Just because there is existing "soft" sediment on the basin floor doesn't mean the pipeline will be largely buried into the sediment naturally. Besides, the prevalent spanning problems in the area will certainly work against the burial.

\subsubsection{5 (and 6.4.2.5) Volcanism}

The report says: "There are no active volcanoes, ..., volcanic vents or rifts in the region."

The statement is accurate but ignores potential volcanic hazards from distant volcanoes in the state of California. A volcano hazard assessment is available for California (Miller, 1989) and an updated assessment of volcanic threat in California is also available (Ewert, and others, 2005). Volcanoes in southern California are more than $200 \mathrm{~km}$ east of the proposed terminal and rated very low threat (Ewert and others, 2005). Hazards from these volcanoes are likely to occur only in the immediate vicinity of the volcanoes (Miller and others, 1989, plate 1).

Volcanoes further to the north include the very high-threat Long Valley caldera, high threat Mono Craters and Inyo Craters, and moderate threat Coso Volcanic Field, Mono Lake Volcanic Field, Red Cones, and Ubehebe Craters. Miller and others (1989, plate 1) present potential ash thicknesses from these volcanoes based on eruptions in the past 10,000 years, and none reach the area of the Liquefied Natural Gas Terminal. However, eruptions larger than these locally precedented events are possible at a number of locations with the closest being the Mono Lake-Long Valley area (Miller and others, 1989, fig. 2). For example, an eruption of $3 \mathrm{~km}^{3}$ of compacted ash similar to the eruption of Mount St. Helens layer Yn from the Long Valley-Mono Lake area would produce an ash fall of around $3 \mathrm{~cm}$ at $450 \mathrm{~km}$ (Miller and others, 1989, fig. 3); the distance to the Liquefied Natural Gas Terminal. However, winds in southern California are generally towards the east (Miller and others, 1989, fig. 2), so that such an eruption were it to happen would have a low probability of depositing significant ash at the location of the Liquefied Natural Gas Terminal. In addition, there are volcanoes in Mexico that might be capable of large eruptions.

\section{References}

Ewert, J.W., Guffanti, Marianne, and Murray, T.L., 2005, An assessment of volcanic threat and monitoring capabilities in the United States-Framework for a National Volcano Early Warning System NVEWS: U.S. Geological Survey Open-File Report 2005-1164, 62 p. [http://pubs.usgs.gov/of/2005/1164/]. 
Miller, C.D., 1989, Potential hazards from future volcanic eruptions in California: U.S. Geological Survey Bulletin 1847, 17 p., 2 plates, scale 1:500,000.

\subsubsection{6: Tsunami: Reviewer 1}

In section 6.1.7.6, the applicant provides a general overview of the processes of tsunami generation, propagation, and runup. In addition, historical tsunami data and a survey of potential tsunami sources is provided. As indicated in the report, the geologic sources for the most severe tsunami hazards are likely from local offshore fault movements and landslides. In contrast, transoceanic tsunamis generated by large magnitude submarine earthquakes around the Pacific Rim are likely to be more frequent, but smaller in size, than local tsunamis.

In terms of the estimated hazard for tsunamis in the area of the LNG facility, the applicant cites several scientific studies published in the academic literature, as well as the hazard level adopted by state and local governments. Design specifications to enable marine oil terminals to withstand tsunamis are discussed within the Marine Oil Terminal Engineering and Maintenance Standards (MOTEMS) by the California State Lands Commission. Specifications applicable to tsunamis appear to be parallel to those for earthquakes motions: that is, $50 \%$ in 50 years and $10 \%$ in 50 years, for Level 1 and Level 2 performance, respectively (Eskijian, 2006). Critical infrastructure such as LNG facilities, however, may need a more conservative probability specification than is described in MOTEMS. A more restrictive probability (for example, $2 \%$ in 50 years) would result in more severe estimated tsunami run up onshore and impact forces on offshore facilities. Rather than adopting a probabilistic estimate, the applicant appears to use the "worst-case" run up estimate of $12 \mathrm{~m}$ adopted by Los Angeles County and the inundation map (fig. 6-30), prepared by the National Tsunami Hazard Mitigation Program (NTHMP) through the California State Office of Emergency Services (OES) for emergency planning purposes. The applicant indicates that the HDD entry (LAX North) is landward of the tsunami inundation zone and above the maximum runup elevation.

It is our understanding that the source for the "worst case" tsunami scenario developed by the NTHMP is a nearby offshore landslide. It is not clear, however, what the source location or what the specific tsunami source parameters are for this worst-case tsunami scenario, to determine whether this is a geologically reasonable landslide. In general, tsunami-wave characteristics, like height and wavelength, from offshore landslides in southern California are highly uncertain. For example, the detailed history of failure for a submarine landslide is critical in estimating tsunami-wave characteristics, but such information can only be obtained through detailed geotechnical modeling, which does not appear to have been performed. At minimum, the impact analysis should include landslides having a wide range of reasonable failure histories to constrain tsunamigeneration parameters and, in general, provide an uncertainty estimate for tsunami runup and inundation.

In terms of the impact analysis for offshore construction (section 6.3.1), the applicant concludes that the DWP and offshore pipelines would not be significantly affected by tsunamis (GEO-4). However, it should be verified that the unique wave mechanics of 
tsunamis have been fully taken into account. Although tsunami waves have occasionally been likened to storm-generated waves, unlike storm waves, the orbital motions for tsunamis involve the entire water column. Moreover, for a given wave height, currents associated with tsunamis are typically much stronger than those from storm-generated waves. Therefore, merely analyzing potential offshore wave height is not sufficient to fully assess the forces on deep-water pipelines and structures that are associated with tsunami waves. Offshore structures in general are subject to inertia (currents) and drag forces from tsunamis; pipelines resting on the seabed may also be affected by lift forces from tsunamis. A detailed analysis of the impact of tsunami waves on offshore structures and pipelines should be conducted, using wave characteristics (height and wavelength) specific to seismogenic and landslide-generated tsunamis. This analysis can then be used to determine if, for example, the pipeline design is adequately ballasted and anchored.

In terms of the impact analysis for onshore construction (section 6.3.2), reasonable measures to mitigate the hazard from tsunamis have been indicated in the report (GEO13). It would be helpful, however, to verify that the scour depth from the worst-case tsunami is less than the depth of the HDD along its full extent (that is, nearshore portion as indicated in CM-GEO-4).

The summary statements and concerns listed above also apply to the AES Alternative DWP and associated onshore pipeline route (Section 6.4.2.5). The applicant indicates that the AES HDD entry location is located landward of the California OES designated tsunami inundation/evacuation zone (presumably developed through the NTHMP, see above) but within the Orange Count/City of Huntington beach tsunami 0-4.5 m elevation impact zone. For the latter, it is unclear how this map was developed, in terms of geologic sources that were considered and hydrodynamic modeling methods that were employed. Often, a particular elevation contour will be used as a proxy to designate a tsunami impact zone, with out taking into account the specific effects of overland flow during tsunami runup. A more accurate determination of the tsunami hazard level at the AES HDD entry location could be made from standardized tsunami modeling procedures.

\section{Reference}

Eskijian, M.L., 2006, Mitigation of seismic and meteorological hazards to marine oil terminals and other pier and wharf structures in California: Natural Hazards, v. 39, p. 343-351.

\subsubsection{Tsunami: Reviewer 2}

Page 6-33 Tsunami - they neglect the study by Borrero and others (2004) with respect to tsunami generated by the San Mateo thrust. They also neglected the Oceanside thrust of Rivero and others (2000), which is in the SCEC community fault model as an alternate fault. 


\section{References}

Borrero, J.C., Legg, M.R., and Synolakis, C.E., 2004, Tsunami sources in the southern California bight: Geophysical Research Letters, v. 31, L13211, [doi:10.1029/2004GL020078].

Rivero, C., Shaw, J.H., and Mueller, K.L., 2000, Oceanside and Thirtymile bank blind thrusts-Implications for earthquake hazards in coastal southern California, Geology, v. 28, p. 891-894.

\subsubsection{Methane Hydrates, Shallow Gas and Seeps: Reviewer 1}

I reviewed and found the section acceptable.

6.1.7.7 Methane Hydrates, Shallow gas and Seeps: Reviewer 2

The discussion matches my knowledge of the subject including direct experience with the mud volcano.

\subsubsection{Methane Hydrates, Shallow Gas and Seeps: Reviewer 3}

Paragraph 1: In this area gas hydrates (if present) are stable at the sea floor in depths below $\sim 600 \mathrm{~m}$. The base of gas hydrate stability will vary depending on water depth, bottom water temperature $\left(\sim 5^{\circ} \mathrm{C}\right)$, and geothermal gradient. In the area of the DWP site the thickness of possible gas hydrate occurrence is within the upper about 100 to 50 meters of sediment. Where the proposed pipeline crosses water depths of less than $\sim 550$ $\mathrm{m}$, gas hydrates should not be considered an issue. In this setting, the most likely change to methane hydrate stability would be long-term changes in bottom water temperatures and local changes in geothermal gradients. In any case, major temperature changes from natural causes during the lifespan of the infrastructure are improbable.

Paragraph 2, sentence 5: "mud volcano" should be "mud volcano-like structure." Insert following reference after "Redondo Beach": Charles K. , William R. Normark, William Ussler III, David W. Caress, Rendy Keaten, 2008, Association among active sea-floor deformation, mound formation, and gas hydrate growth and accumulation within the sea floor of the Santa Monica Basin, offshore California: Marine Geology v. 250, p. 258275.

Paragraph 2, sentence 6: "The source of the gas is thought to be methane hydrate-laden sediments that have become destabilized by faulting along the edge of the Santa Monica Basin." This sentence is not accurate and should be deleted. The gas source is unknown, but is composed almost exclusively of methane from a microbial origin.

Paragraph 2, sentence 7: add Paull and others, 2008 reference after Hein and others, 2005. (See paragraph 2, sentence 5 comment for Paull and others, 2008, reference). They used pushcores and vibracores obtained by remotely operated vehicles.

Paragraph 4, first sentence: We have no evidence for gas hydrate dissociation, unless the authors have evidence that bottom water temperatures have risen recently. 
Paragraph 5: This statement needs to be amplified. One of the real hazards is very-near surface shallow gas that my become unstable and vent during a shaking event. The result may be sagging a slumping of sediment that supports the pipeline.

\subsubsection{Onshore Geologic Hazards-Fault Zones and Seismicity}

1. I do not identify any potential geological hazards that were not already identified and discussed in this section of the report. More specifically, I am not aware of any other faults in the study area that should be taken into account in the design plan. The report section properly takes into account all known strands of the Newport-Inglewood Fault Zone as well as the Charnock Fault.

2. I do not identify the need for any additional studies to be conducted.

6.1.7.8 Onshore Geologic Hazards-Areas Prone to Liquefaction

This section is deficient. The pipeline will be trenched and backfilled along some or all of the sub aqueous route. One source of potential liquefaction hazard that is very serious is the poor quality and compaction of backfill material that will be used to cover the pipeline. The authors need to include a discussion of the potential for liquefaction of backfill soil that will lead the pipeline to either sink or rise depending on its buoyancy at the time of the earthquake.

\subsubsection{Onshore Geologic Hazards - Landslide and Slope Instability: Reviewer 1}

As stated the coastal bluff probably could be an area of potential slope instability. They should evaluate the hazard of a coastal bluff landslide.

\subsubsection{Onshore Geologic Hazards - Landslide and Slope Instability: Reviewer 2}

No specific comments on text. Slope stability in the onshore region does not seem to be an issue. As long as the HDD alignment as it crosses the coastal bluffs stays below the the nominal shelf depth (about $30 \mathrm{ft}$ ) there should be no potential issue for the pipeline. Current proposed HDD elevation at the shoreline is about $120 \mathrm{ft}$.

\subsubsection{8: Onshore Geologic Hazards-Areas Prone to Flooding}

Text on page 6-38 under the subheading "Areas Prone to Flooding": says, "Portions of the LA Basin are subject to periodic storm-induced flooding. The Federal Emergency Management Agency (FEMA) 100-year flood zone map of the onshore pipeline area shows areas subject to flooding"

This is probably all that can reasonably be done to indicate where flooding might be a problem along the pipeline route.

\subsubsection{Mineral Resources}

1. First paragraph, second line: Change

"...fields (greater than 1 billion barrels [ 1 barrel=42 gallons $/ 159$ liters $]$ of reserves)."

to 
“...fields (greater than 1 billion total recoverable barrels [ 1 barrel=42 gallons/159 liters] of oil plus oil equivalent natural gas)."

2. First paragraph, third line: Change

"...there are more than a dozen giant fields with reserves of greater than 100 million barrels."

to

“...there are [more than a dozen] 13 designated giant fields with [reserves of] greater than 100 million total recoverable barrels of oil plus oil equivalent natural gas."

3. First paragraph, fifth line: Change

“...7.6 trillion cubic feet of natural gas."

to

“...7.6 trillion cubic feet of natural gas (Montgomery, 1998)."

4. First paragraph, seventh line: Change

“... and Huntington Beach structures extend offshore (CDOGG 2006)."

to

"....and Huntington Beach structures extend offshore in state waters (CDOGG 2006).”

5. First paragraph, eighth line: Change

“..., 6 miles $(10 \mathrm{~km})$ southwest..."

to

“...8.5 miles $(13.7 \mathrm{~km})$ southwest...”

6. Second paragraph, third line: Change

"The CSLC also administers oil and gas leasing inside..."

to

"The CSLC [also] administers state oil and gas leasing inside..."

7. Third paragraph, fifth line: Change

“...just south of the San Pedro Sea Valley."

To

"...just south of the San Pedro Sea Valley (add reference if different from CDOGG 1972)."

8. Fifth paragraph, first line: Change

"However, the pipeline route..."

to

"However, the offshore pipeline route..."

9. Sixth paragraph, first two lines: Change

"...: the Playa del Rey field and the Potrero field (CDOGG 2006). These fields were active producers as of 2004 (CDOGG 2004)." 
to

"...: the Playa del Rey field (and gas storage reservoir) and the Potrero field (CDOGG 2006). The former was an active producer and the latter abandoned as of 2006 (CDOGG 2006)."

California Division of Oil, Gas, and Geothermal Resources (CDOGG), 1972, California offshore oil and gas seeps:

ftp://ftp.consrv.ca.gov/pub/oil/publications/seeps/CA_offshore_seeps.pdf. Site accessed April 5, 2006.

California Division of Oil, Gas, and Geothermal Resources (CDOGG), 2004, Annual Report, Production by field:

ftp://ftp.consrv.ca.gov/pub/oil/annual_reports/2004/0104prod.pdf, pp83-108. Site accessed April 5, 2006.

California Division of Oil, Gas, and Geothermal Resources (CDOGG), 2006, District 1 oil and gas fields map:

http://www.consrv.ca.gov/dog/maps/index_map.htm Site accessed April 4, 2006.

Montgomery, S., 1998, Increasing reserves in a mature giant: Wilmington field;

Los Angeles basin, part I: reservoir characterization to identify bypassed oil:

American Association of Petroleum Geologists (AAPG) Bulletin Volume 82, pp. 367-385.

\subsubsection{Paleontological Resources}

Two reviewers found no problems with this section. One suggested that if there are opportunities to collect marine mollusks, the L.A. County Museum should be involved.

\subsection{1: GEO-18: Flooding of the Area Above the Buried Pipeline}

Text in section: GEO-18: Flooding of the Area Above the Buried Pipeline says, "Portions of the pipeline route are within the 100-year flood zone, specifically the area within $550 \mathrm{ft}(138 \mathrm{~m})$ of the shoreline. Although the pipeline will be buried throughout this area, it could be subject to inundation and erosion during a 100-year flood."

It strikes me that more work could, and probably should be done, before the pipeline is constructed to provide some indication of how deeply the pipeline should be buried to avoid potential effects from scour during floods. Even a relatively simple analysis relating potential scour depths to the product of flooding depth and energy slope would be helpful. It would involve assessing the maximum depth of flow anywhere the pipeline enters the one-percent flood zone and relating that information to size of the alluvium in the channel and the slope of the energy grade line. In simple analyses the energy grade line is often approximated using the slope of the channel bed. There are probably other USGS scientists who could provide more detailed discussion of what could be done to assess scour. 
There is often a confusing mix of debris flows and "flooding" in this area. My comments only refer to flooding. I noticed that debris flows were mentioned frequently in the document, so it is good to see that debris flows are consider as a separate process. I am not a debris flow expert, so I assume someone else is looking at this potential hazard.

\subsection{Alternatives: General comments}

This section identifies a suite of geologic hazards offshore southern California that could impact an alternative location for their proposed LNG DWP facility, its associated pipelines and RLNGC vessels. The DWP submersible buoys, manifolds, and risers would be situated on the floor of the Gulf of Santa Catalina, in $800 \mathrm{~m}$ of water, about 35 $\mathrm{km}$ southwest of Dana Point. Twin 24 inch diameter pipelines would extend northward across the gulf floor, skirting east around Lausen Knoll, up the inner continental slope between San Gabriel and Newport submarine canyons, and across the Continental Shelf.

Potential geologic hazards identified by Fugro for Woodside Natural Gas include various earthquake hazards, slope failure, and methane seeps. In particular, the pipeline route crosses two active RL SS faults (Palos Verdes-Coronado Bank Fault; NewportInglewood-Rose Canyon Fault), a presumed-active buried thrust fault (THUMSHuntington Beach fault), and a continental slope covered with slump deposits. In addition, the alternative DWP is situated $10 \mathrm{~km}$ northwest of the active Catalina Escarpment-San Diego Trough Fault Zone.

1. Most comments pertaining to Section 6.4 (see above) are also relevant to the proposed alternative location offshore Orange County and to an alternative southern LAX route for the pipeline offshore Santa Monica.

2. This section lacks a map showing the location of many geographic names mentioned in the text. Could not find fig. 6-47.

3. Sub-section 6.1.4.1 suggests that the Palos Verdes Fault is segmented and that the southern segment is more active than the northern one, with a higher slip rate (3 $\mathrm{mm} / \mathrm{y}$ versus $1.5 \mathrm{~mm} / \mathrm{y}$ ) and higher expected moment magnitude ( $\mathrm{Mw} 7.0$ versus 6.6). However, fig. 6-20 (peak ground acceleration; same as fig. 6-41) implies that the northern segment is more seismically active. This apparent conflict needs to be explained in the text.

4. The potential tsunami inundation zone (Figure 6-45) needs to be updated when the City of Huntington Beach completes its tsunami impact mapping.

5. This section does not evaluate the potential for differential ground subsidence along the onshore portion of the pipelines - related to petroleum withdrawal from the active fields they cross or skirt (West Newport, Huntington Beach, and Talbert fields) - and whether the resultant differential stresses might affect the integrity of the pipelines.

6. The report lacks data needed to adequately estimate slip rates or expected slip events on active faults crossed by pipelines, current mobility of slumps mapped beneath pipeline route on inner continental slope, or the impact of the 1933 M6.4 "Long Beach" earthquake in terms of strong ground motion, liquefaction or submarine slope failure. Unclear whether new high resolution geophysical surveys mentioned in the report will include data acquisition for alternative site(s). 


\subsubsection{Geologic Setting: Reviewer 1}

Change Lausen Knoll to Lasuen Knoll throughout the document.

Page 6-49, paragraph 1. However, the Palos Verdes Fault Zone scarp does not necessarily indicate east-side-up offset along the Palos Verdes Fault.

Page 6-49, paragraph 6. As already mentioned, the new USGS data suggests that the Palos Verdes Fault does not connect with the Coronado Bank Fault.

6.4.2.1 Geologic Setting: Reviewer 2

Page 6-48 last paragraph.: Graham and Bachman (1983) show Newport Canyon in part controlled by Newport-Inglewood Fault Zone.

\section{Reference}

Graham, S.A., and Bachman, S.B., 1983, Structural controls on submarine-fan geometry and internal architecture - upper La Jolla fan system, offshore southern California: AAPG Bulletin, v. 67, no.1, p.83-96.

\subsubsection{2: Reviewer 1}

Under subsection 6.4.2.2, the THUMS-Huntington Beach Fault is identified as "an active seismic source," however, under sub-section 6.4.2.5, this fault is identified as "potentially active." This conflict needs to be resolved.

\subsubsection{Structure and Seismicity: Reviewer 2}

Page 6-49- the San Diego Trough Fault Zone extends to north into area of the alternate site (and may extend further north to San Pedro Basin Fault).

6.4.2.3 Anticipated Conditions at the HDD for the AES Alternative: Reviewer 1 It's unclear whether the report attributes fault scarps and other vertical discontinuities along the Newport-Inglewood fault (that is, Newport-Inglewood Fault Zone uplift) to a vertical component of fault displacement or to a lateral juxtaposition of differing stratigraphic sequences.

6.4.2.3 Anticipated Conditions at the HDD for the AES Alternative: Reviewer 2 I reviewed and found the section acceptable.

6.4.2.3 Anticipated Conditions at the HDD for the AES Alternative: Reviewer 3 Conditions are appropriately characterized, except for mentioning the existence of the coarse-grained Talbert aquifer located within the Santa Ana gap and which may cause some hole stability problems due to the non-cohesive nature of the materials. The Talbert, however, is identified in the next section and in the cross section. 
(Minor) typo - the last sentence of this section identifies that the stratigraphy is discussed in greater detail in section 6.5.4.4. There is no such section-should be corrected to 6.4.2.4.

\subsubsection{Stratigraphy: Reviewer 1}

See first reviewer's comments under section 6.1.3.1.

\subsubsection{Stratigraphy: Reviewer 2}

I don't have any specific comments on the text. The report coverage is general, sparse, and based on limited (and old) stratigraphic knowledge. Accordingly, their characterization of the stratigraphy may not apply to specifics along the LAX HDD alignment location. Additional studies (borings and geophysics) likely would be valuable here to tie the onshore and offshore geology together.

\section{Section 6.4.2.4 Stratigraphy: Reviewer 3}

No specific comments on the text. However, the characterizations discussed here are general, based on an old stratigraphic framework and may not directly apply to the specific conditions along the HDD alignment. If this alternative is further considered, a more detailed, site-specific evaluation of the onshore and offshore geologic conditions and engineering properties would be required.

Overall, the location of the HDD for the AES Alternative poses additional geologic hazards onshore from possible liquefaction and flooding, as opposed to the proposed project location.

\subsubsection{Geologic Hazards-Strong Ground Motions}

See strong ground motion comments under section 6.1.7.2.

\subsubsection{Geologic Hazards-Surface Fault Rupture}

The definition adopted for "historically active" and "active" faults (subsection 6.4.2.5) requires evidence for surface rupture even though recent damaging earthquakes in southern California have occurred on "blind" thrust faults. The report needs to consider whether the definition of "active" faults should be expanded.

Under subsection 6.4.2.2, the THUMS-Huntington Beach fault is identified as "an active seismic source," however under sub-section 6.4.2.5, this fault is identified as "potentially active." This conflict needs to be resolved.

\subsubsection{Geologic Hazards_-Liquefaction/Lateral Spreading}

This section focuses on the liquefaction and lateral spread hazard in the onshore and is deficient in that it neglects offshore hazards on the shelf where sands, which are fully saturated and noncohesive, could liquefy. 
6.4.2.5. Geologic Hazards - comment applies to both Liquefaction/Lateral Spreading and Mass Movement sections

Not much information is provided here about hazards for the AES Alternative route in the Newport Beach area. The Newport Canyon system (or parts thereof) is currently active and, as such, presents risks of sediment failure that might impact pipeline safety. Additional studies will be needed if this alternative is found to be preferred over the Santa Monica Basin/LAX route.

6.4.2.5 Geologic Hazards-Mass movement: slumps, slides, debris flows, turbidity currents

There is not much material in this section about mass movement hazards. However, because the AES Alternate passes near the Newport Canyon complex and part of Newport Canyon is presently active, this slope has a much higher risk of failure, debris flows and turbidity currents than that along the Santa Monica Bay route. A significantly greater effort at evaluating the safety of this slope is needed.

\subsubsection{Geologic Hazards-Volcanism: see section 6.1.7.5}

\subsubsection{Geologic Hazards-Shallow Gas, Oil, and Gas Seeps, Methane Hydrates:}

\section{Reviewer 1}

I reviewed and found the section acceptable.

6.4.2.5 Geologic Hazards-Shallow Gas, Oil, and Gas Seeps, Methane Hydrates:

\section{Reviewer 2}

To the best of my knowledge, there are no seeps in this area.

\subsubsection{Mineral Resources}

Reviewer had no comments on this section.

\subsubsection{Unique Geologic or Paleontological Resources}

Two reviewers found no problems with this section. One suggested that if there are opportunities to collect marine mollusks, the L.A. County Museum should be involved.

\subsubsection{LAX South Shore Crossing Alternative: Reviewer 1}

All onshore routes and facilities must take into account the possibility that old abandoned (sometimes poorly abandoned) exploratory and production wells and other buried oil-related hardware may be intersected during excavation and drilling operations. If old drillholes, wells, or other hardware are encountered, hazards may be generated and project costs may be impacted. Careful coordination with the California Division of Oil, Gas, and Geothermal Resources (CDOGG) who maintains historical records of drilling activity will be necessary.

\subsubsection{LAX South Shore Crossing Alternative: Reviewer 2}

I reviewed and found the section acceptable. 


\subsection{3 - LAX South Shore Crossing Alternative: Reviewer 3}

No specific comments on the text. I concur with the conclusions of this section that the LAX south shore alternative would likely produce more impacts and may be subject to greater hazards due to a greater number of submarine channel crossings and proximity to bottom sand and gravel indicative of higher wave and current action than inferred for the project location.

\subsubsection{Onshore Pipeline Alternatives: Reviewer 1}

See Reviewer 1 comments under section 6.4.3.

\subsubsection{Onshore Pipeline Alternatives: Reviewer 2}

I reviewed and found the section acceptable.

\subsubsection{Onshore Pipeline Alternatives: Reviewer 3}

No specific comments on text. I concur that the alternate routes are not (from a hazard or design standpoint) significantly different from that proposed. With respect to the onshore pipeline crossings, all proposed alignments will cross the Potrero Fault. This fault did not appear to be discussed much in the report. I would recommend additional fault study investigations (to determine the actual surface expression and activity) of the Potrero Fault to assist in design of the crossing there. This is identified in Conservation Measure CM-GEO-10 (page 6-44), and I believe such investigations are necessary and appropriate.

\subsubsection{Alternative RCTS Location: Reviewer 1}

See Reviewer 1 comments under section 6.4.3

\subsubsection{Alternative RCTS Location: Reviewer 2}

I reviewed and found the section acceptable.

\section{Section 6.4.7 Alternative RCTS Location: Reviewer 3}

No specific comments on this section. From a geologic standpoint, I see no advantage or disadvantage to the alternative, as concluded in the report.

\section{General Comments and Comments on Tables, Figures, Appendixes}

\section{Table 6-1 Estimated Characteristics of Potential Seismogenic Sources}

The slip rate estimate in table 6-1 of $3 \mathrm{~mm} / \mathrm{yr}$ for the Coronado Bank Fault comes from the assumption that the Coronado Bank Fault connects to the Palos Verdes Fault, which is about the only fault in this area with a published slip rate. However, if these faults do not connect, then this slip rate is not applicable to the Coronado Bank Fault.

\section{Figure 6-24}

This figure clearly shows the San Pedro Basin Fault (C-C', traces at about 8000-9000 feet along the line, offsets the sea floor) — although the Geological Resources document 
shows the fault as inferred on its map. Also, although from the figure it is difficult to tell, there seems to be faulting on the shelf on profile D-D' that may offset transgressive surface. They have a very tight grid of reflection data, but I am not sure how it was utilized for seismic hazards - it seems as if there should be more input from this data set.

\section{Figure 6-42}

Reference on Saucedo and others should read 2003, not 2005.

\section{Appendix L}

On page 20, in the discussion following the heading "Santa Monica Basin" the thickness value range is omitted for the pre-Quaternary marine sediments to which the paragraph refers. There are three citations from the literature to cover the point, but no number is supplied.

\section{Appendix M}

See comments by multiple reviewers under 6.1.7.1 that also address 6.1.7.2 and appendix M.

\section{General Comment on Pipeline Location}

One thing that might be worth looking at is to investigate a slight alteration in the pipeline route across the shelf break. From past milepost 23 to milepost 27, the proposed alignment traverses the slope obliquely and crosses several slope channels. If the pipeline were to trend in a more northerly alignment that parallels the channels from just past milepost $23+00$ to the slope break, and then return to the proposed alignment near milepost $28+00$, there would be fewer channel crossings and less potential for hazards to the pipeline due to slope processes. The downside would be a somewhat steeper slope for the traverse and perhaps an additional 0.5 to 1 mile of pipeline length. However, it seems that some minor modifications in the planned route might be worth looking into, as it appears that this region is the one location (besides the inner shelf where the pipeline is buried) where surficial process could produce a hazard to the pipeline. 